\title{
International Collaboration Formation in Entrepreneurial Food Industry: Evidence of an Emerging Economy
}

Seyed Hossein Razavi Hajiagha

Department of Management, Faculty of Management and Finance, Khatam University, Tehran, Iran

h.razavi@khatam.ac.ir

Saeed Alaei

Department of Industrial Engineering, Faculty of Engineering, Khatam University, Tehran, Iran

s.alaei@khatam.ac.ir

Hannan Amoozad Mahdiraji

${ }^{1}$ Leicester Castle Business School,

De Montfort University, Leicester, United Kingdom

hannan.amoozadmahdiraji@dmu.ac.uk

Fatemeh Yaftiyan

Faculty of Management, University of Tehran, Tehran, Iran

Fatemeh.yaftiyan@ut.ac.ir 


\title{
International Collaboration Formation in Entrepreneurial Food Industry: Evidence of an Emerging Economy
}

\begin{abstract}
Purpose. International collaboration is a crucial requirement of entrepreneurship, particularly in developing emerging economies. This collaboration seems so necessary in the food industry as a major contributor to environmental, social, and economic problems. This paper aims to identify, analyse the influential network relationship, and prioritise the Key Success Factors (KSFs) of international collaboration formation in the entrepreneurial food industry with a case study on Iran's emerging economy.
\end{abstract}

Method. To identify a list of KSFs, a qualitative method, literature review, is initially used. A quantitative method, fuzzy-Delphi, then is employed to finalise the main KSFs based on the entrepreneurial food industry experts' opinion. To analyse the causal relationship, and prioritise the KSFs, a fuzzy Decision Making Trial and Evaluation Laboratory (DEMATEL)-Analytic Network Process (ANP) methodology, i.e. FDANP, is applied. At the first stage, the cause-effect diagram of KSFs is extracted using fuzzy DEMATEL and then, the KSFs weights and priorities are evaluated using a fuzzy ANP.

Findings. The results illustrate that the characteristics of effective development workers are the leading dimension of a successful international collaboration that directly affects other dimensions. On the other hand, increased marketing and trading is the most important KSF that is directly related to international entrepreneurial collaboration team capabilities and professionalism. The leading and casual role of team members also plays a vital role in strategic and communication issues affecting the collaboration success, e.g. market research and new product development. Availability of financial resources and the ability of partners in continuous financing is also a crucial and required factor for a successful collaboration.

Originality. Using an extensive review of the literature to extract the KSFs of international entrepreneurial collaboration and finalising them using a fuzzy-Delphi method and examining the cause-effect relations between them, as well as prioritising the KSFs are the main contributions of this paper.

Keywords. International Collaboration Formation, Fuzzy DEMATEL, Fuzzy ANP, Entrepreneurial Food Industry, Emerging Economy 


\section{Introduction}

The food industry is a well-established, mature and complex multitier system (Flammini et al., 2017). Through its producers, processors, distributors, consumers, and regulators, it is responsible for improving public nutrition and health (Sibbel, 2012). The food industry is also a competitive system with 96 percent of small and medium enterprises (SMEs) (Lim and Antony, 2019), which are the critical components in economic growth, employment and national development, especially in developing countries (Ahadi and Kasraie, 2020). In this respect, the Food industry contributes to the growth of the local and global economy, e.g. in terms of both turnover (i.e. $€ 1,244$ billion) and employment (i.e. 4.2 million people); it is the greatest manufacturing industry in Europe (Flammini et al., 2017). Besides, the food system is considered a major contributor to environmental, social and economic problems (Lynde, 2020; Mazzucchelli et al., 2021). In this light, it is required to design a new food system that is focused on planetary health and the health and well-being of humans and animals (Lynde, 2020). To do so, the need for innovation and entrepreneurship in the food industry is undeniable and hence the investment in this specific field is growing globally (Lynde, 2020; Jafari-Sadeghi et al., 2021a).

Entrepreneurship is defined as a creative and innovative capability to commercialise a new product, service, process, venture, or business idea (Knudson et al., 2004). Entrepreneurship as an element of countries economic development, particularly in developing countries, grows rapidly in the food industry (Lynde, 2020; Erista et al., 2020; Lim and Antony, 2019; JafariSadeghi et al., 2021b). It is also introduced as a signal that leads to a great change in the food system (Lynde, 2020). Several recent surveys focused on entrepreneurship in the agri-food industry and identified the factors triggering entrepreneurs to start the new business. In this regard, both innovation and risk-taking are the main dimensions of entrepreneurial orientation (Erista et al., 2020; Hutahayan, 2019). Also, perceived feasibility, readiness and conviction are influential factors on intention as a strong predictor to start entrepreneurial start-ups ( Yaseen et al., 2018). (Blažková and Dvouletý, 2019) Found that productivity is a significant factor of entrepreneurial success. Besides, the new challenges of entrepreneurship in the food industry are (1) Need of thinking more broadly about opportunities and implications of the entire food value chain (Lynde, 2020; Petruzzelli and Svejenova, 2016), (2) Need for a collaborative and comprehensive approach to fill the existent gap knowledge between stakeholders (Lynde, 2020; Sibbel, 2012), (3) Develop online community engagement during pandemic circumstances, e.g. COVID-19, in the food industry based on technology and particularly the internet called cyber entrepreneurship (Tajvidi and Tajvidi, 2020; Jafari-Sadeghi et al., 2021c).

Moreover, entrepreneurship plays a critical role in developing emerging economies (Bruton et al., 2008). A review of recent studies carried out in this field indicates that internationalisation of entrepreneurship of emerging economies is a new challenge, e.g. (Jafari Sadeghi and Biancone, 2019) emphasised the significance of international entrepreneurship of emerging economies, and (Zahra and Garvis, 2000) in their research examining how entrepreneurs in emerging economies use their knowledge to increase their profitability in the international marketplace. Though entrepreneurship is a key factor for converting emerging economies to major economic forces in the world, more research on this domain seems necessary (Bruton et al., 2008). Besides, the extensive growth of emerging economies has made a change in terms of increasing food products demand (Jack et al., 2014). (Lim and Antony, 2019) argued that the food industry will grow rapidly in developing countries. There are some papers that they 
have researched on the food industry in emerging economies with the issue of identifying the influential social sustainability factors in the food industry supply chain (Khan et al., 2020), development of food system on poor urban consumers (Figuié \& Moustier, 2009), how innovation and skills impact on agri-food sector (Jack et al., 2014), marketing strategy development based on consumer preferences and behavior (Ali et al., 2010). Also, competition growth due to globalisation is a challenge for firms of the food industry in emerging economies to maintain their competitive advantages via entrepreneurship and innovation. In other words, success in internationalisation requires creatively leveraging the resources and skills in international markets (Zahra and Garvis, 2000; Jafari-Sadeghi et al., 2021d).

Due to the complexity of the food industry and whispered concerns about accelerating changes in technology, environment and consumer's preference, and also the pressure of the food safety regulations approved by the government and non-governmental organisations, the success of stakeholders (i.e. SMEs and new entrants) to reduce the risks of entrepreneurial activities in international markets depends on their capability to innovate via collaboration with each other (Flammini et al., 2017). (Aggarwal \& Srivastava , 2016) argued that collaboration in the agri-food supply chain leads to low wastage and better efficiency. (Dung et al., 2020) In their research pointed out the entrepreneurial orientation and collaborative performance have a positive relationship in the agri-food industry in emerging markets. Despite several recent papers emphasised the importance of international collaboration in the food industry, e.g. (Bombaywala and Riandita, 2015) believed that interaction, collaboration, and information sharing play an important role in innovation in the food industry, and ( $\mathrm{Li}$ et al., 2012) concluded that international collaboration is an effective factor of food safety assessment and management, there is a lack of research on international collaboration in the entrepreneurial food industry. As evident, (Lynde, 2020) recommended that a new food system is required in which entrepreneurs require constructed broadly collaboration between shareholders.

KSFs are the minimum capabilities required for the industry or a company to enter the competition (Ketelhöhn, 1998). The concept of KSF is a key strategic one and has been widely used in business research (Aschemann-Witzel, et al., 2017), particularly in the food industry, e.g. its application is found in new product development (Suwannaporn \& Speece, 2010), evaluation of quality management practices (Habibah Abdul Talib et al., 2014), food safety improvement (Taylor and Taylor, 2015), food waste reduction (Aschemann-Witzel, et al., 2017), business performance examination ( Hutahayan, 2019), sustainability of food supply chain (Sharma et al., 2018; Jafari-Sadeghi et al., 2020) and entrepreneurial decision-making and success (Blažková and Dvouletý, 2019). Despite limited research on identification and investigation of KSFs that drive international collaboration, a review of recent papers reveals that availability of both appropriate partners and funding from private (or government) sources, leadership, interdependence, communication, information and resource sharing, professional commitment, teamwork and flexibility, trust between partners, personal characteristics of those involved, overcoming cultural differences and enough technical expertise (Hines et al., 2010; Badraoui et al., 2020; Bombaywala and Riandita, 2015) are KSFs of international collaboration and it remains an important issue. As mentioned later, the formation of international collaboration in the entrepreneurial food industry is a novel issue and understanding its KSFs and their relationships is critical for entrepreneurs of emerging economies to enter the competitive international markets. 
Although extensive research has been carried out on entrepreneurship in the food industry and emerging economies, the existing body of literature does not adequately cover the identification and investigation of KSFs and their relationships in international collaboration formation in the entrepreneurial food industry in emerging economies. To contribute to bridging this gap, this paper examined IRAN, as an emerging economy, which has the potential of being an entrepreneurial powerhouse (Rezaei et al., 2017; Rezaei et al., 2021). To do so, a list of mentioned KSFs is explored via qualitative analysis i.e. literature review and fuzzy-Delphi method. Through the implementation of a fuzzy quantitative approach, DEMATEL and ANP, the ranking and identifying the network relationships of explored KSFs are carried out.

The Remainder of this paper is organised as below. A literature review is presented in section 2. At the end of section 2, a list of KSF is extracted from the literature. The research methodology is then described in section 3. To finalise the identified KSFs, a Delphi method is deployed in section 4 and the cause-effect relation among KSFs and their priorities are evaluated using the FDANP. Discussion and implications are provided in section 5. Finally, section 6 is devoted to the conclusion and future recommendation.

\section{Literature review}

As stated later, whispered concerns of food sciences and quality assurance on food safety and hygiene (Ogden and Grigg, 2003; Fotopoulos, et al., 2010; Boudlaie et al., 2020) and also the food industry's impact on environmental, social and economic problems (Lynde, 2020), leads to a wide number of studies in the food industry in last two decades (Scopus, 2021). However, it requires further research, particularly in the perspective of international entrepreneurship in emerging economies. To this end, this section reviews a range of different works of literature in the food industry to (i) represent the current state of knowledge and the relevant research gaps in the aforementioned field, and (ii) identify the KSFs in international collaboration formation in the entrepreneurial food industry. Table 1 summarizes the results of reviewing the most relevant researches from 1999 to 2019.

\section{$\underline{\text { Insert Table } 1}$}

The conducted literature review indicates that recent scholars have mainly used KSF theory in the food industry to address the problems related to rapidly changing consumers tastes and continuously advancing technology (Suwannaporn \& Speece, 2010), the lack of quality management practices (Habibah Abdul Talib et al., 2014), the importance of both safety and security in the food sector (Taylor \& Taylor, 2015) and also management of security and safety of food commodities in food logistics (Shankar et al., 2018), consideration of new ventures and entrepreneurship as economic indicators of a nation's economic health and prosperity (Kirkley, 2016), growing awareness for the need for sustainability (Long et al., 2017) and the importance of sustainable and cleaner production and consumption (Aschemann-Witzel, et al., 2017), the importance of studying SMEs performance (Hutahayan, 2019), a short of unequivocal research on firm-specific factors in the food processing industry (Blažková and Dvouletý, 2019). In this regard, the extraction of KSFs associated with entrepreneurship activities in the food industry is conducted in (Kirkley, 2016) and (Blažková and Dvouletý, 2019). However, none of the studies have employed the KSF theory for international collaboration formation in the entrepreneurial food industry. Besides, the most of declared researchers have recently used literature review and in-depth interviews to extract KSFs. Also, most of the work has applied qualitative 
methodologies to investigate the KSF's relationships. Sharma, et al., (2018) have applied fuzzy AHP and others have mostly used statistical methods, e.g. ANOVA (Suwannaporn \& Speece, 2010) and regression analysis (Mazzucchelli, et al., 2021). Despite the uncertain environment, fuzzy data have been slightly used (see Table 1). To contribute to filling this gap, this paper employs a literature review and Delphi approach to extract KSFs in international collaboration formation in the entrepreneurial food industry in the emerging economy of Iran. Then, it employs a fuzzy quantitative approach, DEMATEL and ANP, as a hybrid MCDM method, to identify the influential network relationships of KSFs and prioritise them. Moreover, these findings provide authors with empirical support to the existing literature on the KSFs in international collaboration formation in the entrepreneurial food industry. Thus, a list of fifty-five KSFs along with a brief description of each one is proposed in Table 2 .

\section{Insert Table 2}

\section{Methodology}

In the current study, a three-stage research method is used to identify, analyse the causal relationship, and prioritise the KSFs on international collaboration formation in the entrepreneurial food industry. First, the KSFs are identified using literature review and using a survey among food industry entrepreneurs, they are finalised. Indeed, a fuzzy-Delphi method is used to finalise the KSFs based on experts group opinions (Kumar et al., 2019). Then, a Fuzzy DEMATEL-ANP (FDANP) methodology is employed. The fuzzy DEMATEL technique is applied to construct an influential network relationship of KSFs, where the fuzzy ANP is applied to prioritise them (Khalilzadeh et al., 2021; Mavi and Standing, 2018). In more detail, to analyse the causal relationship between KSFs, MCDM choices are limited to DEMATEL, ISM (Interpretive Structural Modelling), MICMAC (Matriced' Impacts Croise's Multiplication Applique'e a UN Classement), etc. (Pilar and Bongo, 2019; Liang et al., 2016; Nagpal et al., 2017). DEMATEL is a preferred technique since it would be provided authors with a structural map of the system based on the interrelations among the cause and effect KSFs (Mavi and Standing, 2018; Mahmoudi et al., 2019). As further advantages, DEMATEL provides a feasible solution by introducing and mapping a hierarchical relationship network, which can tackle a decision-making dilemma when a cause has multiple effects or vice versa (Ullah et al., 2021). Besides, it offers both visual and numerical advantages for visualising the intensity of the relations and their importance using graphs theories and matrix computations (Ullah et al., 2021). Similarly, despite wide calculations and additional pairwise comparison matrices compared with Analytical Hierarchy Process (AHP), the ANP has been known as a well-suited complementary technique for DEMATEL to determine KSFs weight and priority based on experts' opinions (Salehi et al., 2020; Mavi and Standing, 2018). As to the advantages, the ANP is more accurate and feasible under interdependent situations (Liao and Chang, 2009). ANP is able to link dynamic factors dealing with the complicated interdependencies and complex relationships among them (Dagdeviren and Yuksel, 2010; Chen, 2016). Additionally, fuzzy numbers are used in place of crisp ones to handle the vagueness and uncertainty of human judgments (Karuppiah et al., 2020). Given that the experts group is more familiar with the fuzzy concept as compared with other uncertain approaches, e.g, hesitant fuzzy, intuitionistic fuzzy, interval fuzzy, etc. Moreover, some requirements for applying new aforementioned uncertain approaches have not been achievable in this study, e.g. nonmembership estimation based on experts' opinions (Garousi Mokhtarzadeh et al., 2020). These are the reasons behind using 
FDANP methodology to reach the aims of this paper, mapping influential network relationship of KSFs, weighing and prioritising KSFs.

Data collection in this paper was taken from previous literature and opinion from both practitioners and managers of the entrepreneurial food industry. To this end, structured questionnaires and online in-depth interviews are used. Each aforementioned expert was assigned approximately an hour to fill the online structured questionnaire. To this end, a structured questionnaire involving two parts, the first and second parts related to the fuzzy DEMATEL and fuzzy ANP, respectively, distributes among considered experts through a group online session. Each aforementioned expert was assigned approximately three hours to fill the structured questionnaire. The current section explained the employed methodology. First, a brief definition of a triangular fuzzy number is given.

Definition 1. A fuzzy number $\widetilde{B}=(l, m, u)$ is a Triangular fuzzy number (TFN) when its membership function is as follows.

$$
\mu_{\tilde{b}}(x)=\left\{\begin{array}{cc}
0 & x<l \\
\frac{x-l}{m-l} & l \leq x \leq m \\
\frac{u-x}{u-m} & m \leq x \leq u \\
0 & x>u
\end{array}\right.
$$

Where $l, m$, and $u$ are real numbers and $l \leq m \leq u$.

Definition 2. The algebraic operations of two TFN $\widetilde{B_{1}}=\left(l_{1}, m_{1}, u_{1}\right)$ and $\widetilde{B_{2}}=\left(l_{2}, m_{2}, u_{2}\right)$ can be defined as follows.

$$
\left\{\begin{array}{l}
\widetilde{B_{1}} \oplus \widetilde{B_{2}}=\left(l_{1}+l_{2}, m_{1}+m_{2}, u_{1}+u_{2}\right) \\
\widetilde{B_{1}} \ominus \widetilde{B_{2}}=\left(l_{1}-u_{2}, m_{1}-m_{2}, u_{1}-l_{2}\right) \\
\widetilde{B_{1}} \otimes \widetilde{B_{2}}=\left(l_{1} \times l_{2}, m_{1} \times m_{2}, u_{1} \times u_{2}\right) \\
\widetilde{B_{1}} \oslash \widetilde{B_{2}}=\left(l_{1} / u_{2}, m_{1} / m_{2}, u_{1} / l_{2}\right) \\
\lambda \odot \widetilde{B}=\left\{\begin{array}{l}
(\lambda l, \lambda m, \lambda u), \lambda \geq 0 \\
(\lambda u, \lambda m, \lambda l), \lambda<0
\end{array}\right.
\end{array}\right.
$$

\subsection{FDANP method}

The procedure of the FDANP method is described in this section. Consider $m$ criteria and $n$ dimension of criteria. Each dimension $k$ where $k=1,2, \ldots, n$ consists of $m_{k}$ number of criteria as: $D_{k}=\left\{c_{k 1}, c_{k 2}, \ldots, c_{k, m_{k}}\right\}$. The total number of criteria is $m_{l}+m_{2}+\ldots+m_{n}=m$. The inputs of the FDANP method are pairwise comparisons of $K$ experts regarding the different degrees of "influence" between criteria/dimensions. The influential weights of criteria and dimensions are the main outputs of this method. The FDANP includes two stages. Stage 1 applies a fuzzy DEMATEL technique to obtain the total relation matrix and cause/effect diagram. The procedure is summarised in Steps (1-6) (Mahmoudi et al., 2019; Mahdiraji et al., 2021); and, Stage 2 determines the influential weights of criteria/dimensions based on the foundation concept of ANP (Saaty, 1996). The procedure is summarised in Steps (7-10) (Dinçer et al., 2019). 
Stage 1. Calculating the total relation matrix and constructing the cause/effect diagram for both criteria and dimensions.

Step1. Designing of appropriate fuzzy linguistic scale. A linguistic scale as shown in Table $3 \mathrm{~b}$ is established for pairwise comparisons to define the different degrees of "influence" between criteria/dimensions.

\section{$\underline{\text { Insert Table } 3}$}

Step 2. Extracting the fuzzy initial direct relation matrix. The relationship between characteristics $F_{1}, F_{2}, \ldots, F_{n}$ is measured using linguistic terms, and, the corresponding TFN $\tilde{F}_{i j}=\left(l_{i j}, m_{i j}, u_{i j}\right)$ is the direct relation between $F_{i}$ and $F_{j}$. In the case of group decision making including $K$ experts, the aggregated viewpoint of experts can be calculated as follows:

$\tilde{d}_{i j}=\frac{\sum_{k=1}^{K} \tilde{F}_{i j}^{k}}{K}=\left(\frac{\sum_{k=1}^{K} l_{i j}^{k}}{K}, \frac{\sum_{k=1}^{K} m_{i j}^{k}}{K}, \frac{\sum_{k=1}^{K} u_{i j}^{k}}{K}\right)$

Where $\tilde{F}_{i j}^{k}=\left(l_{i j}^{k}, m_{i j}^{k}, u_{i j}^{k}\right)$ is the fuzzy evaluation of the $k^{\text {th }}$ expert. The fuzzy initial direct relation matrix $D$ for $n$ characteristics $F_{1}, F_{2}, \ldots, F_{n}$ is an $n \times n$ matrix as follows:

$\widetilde{D}=\left[\tilde{d}_{i j}\right]_{n \times n} \quad i, j=1, \ldots, n$

Note that elements $\tilde{d}_{i j}$, it will be regarded as a $\operatorname{TFN}(0,0,0)$, when $i=j$.

Step 3. Normalising the fuzzy initial direct relation matrix. The normalised direct-relation fuzzy matrix is denoted as follows.

$\widetilde{N}=\left[\tilde{n}_{i j}\right]_{n \times n} \quad i, j=1, \ldots, n$

$\tilde{n}_{i j}=\tilde{d}_{i j} / \max _{1 \leq i \leq n} \sum_{j=1}^{n} u_{i j}$

Step 4. Calculating the fuzzy total relation matrix. The fuzzy total relation matrix $\tilde{T}$ can be computed as follows.

$\tilde{T}=\left[\tilde{t}_{i j}\right]_{n \times n}=\lim _{p \rightarrow \infty}\left(\widetilde{N}+\widetilde{N}^{2}+\cdots+\widetilde{N}^{p}\right)$

Step 5. Defuzzifying the fuzzy total relation matrix. The defuzzified values of the total influence matrix $\tilde{T}$ can be obtained using converted fuzzy data into crisp scores (CFCS) method which is introduced by (Opricovic and Tzeng, 2003; Dorcheh et al., 2021). CFCS method is performed in the following four steps.

(i) Normalisation. For triangular fuzzy numbers $\tilde{t}_{i j}=\left(l_{i j}^{t}, m_{i j}^{t}, u_{i j}^{t}\right)$ belonging to $\tilde{T}$, the normalised matrix $\tilde{X}=\left[\tilde{x}_{i j}\right]_{n \times n}$ can be obtained as follows.

$\tilde{x}_{i j}=\frac{\tilde{t}_{i j}-\min _{i} l_{i j}^{t}}{\max _{i} u_{i j}^{t}-\min _{i} l_{i j}^{t}}$ 
(ii) Computing left and right normalised values. Assuming $\tilde{x}_{i j}=\left(l_{i j}^{x}, m_{i j}^{x}, u_{i j}^{x}\right)$ belonging to the normalised matrix $\tilde{X}=\left[\tilde{x}_{i j}\right]_{n \times n}$, the left and right normalised bound matrix $L R=\left[\left(l_{i j}^{b}, r_{i j}^{b}\right)\right]_{n \times n}$ is calculated as follows:

$l_{i j}^{b}=\frac{m_{i j}^{x}}{1+m_{i j}^{x}-l_{i j}^{x}}$

$r_{i j}^{b}=\frac{u_{i j}^{x}}{1+u_{i j}^{x}-m_{i j}^{x}}$

(iii) Computing the normalised crisp values. Assuming $L R=\left[\left(l_{i j}^{b}, r_{i j}^{b}\right)\right]_{n \times n}$ as the left and right normalised values, the normalised crisp matrix $C=\left[c_{i j}\right]_{n \times n}$ is calculated as follows:

$c_{i j}=\frac{l_{i j}^{b}\left(1-l_{i j}^{b}\right)+r_{i j}^{b} \times r_{i j}^{b}}{1-l_{i j}^{b}+r_{i j}^{b}}$

(iv) Computing the final crisp values. The final crisp matrix $Z=\left[z_{i j}\right]_{n \times n}$ can be calculated as follows:

$z_{i j}=\min _{i} l_{i j}^{t}+c_{i j} \times\left(\max _{i} u_{i j}^{t}-\min _{i} l_{i j}^{t}\right)$

Step 6. Constructing cause-effect diagram. Regarding the final crisp matrix $Z=\left[Z_{i j}\right]_{n \times n}$, the cause-effect diagram can be created by using the following equations.

$R_{i}=\sum_{j=1}^{n} z_{i j}$

$C_{j}=\sum_{i=1}^{n} z_{i j}$

Where $R_{i}$ and $C_{j}$ represent the summation of rows and columns of the final crisp matrix $Z$, respectively. A cause-effect diagram can be created using $\left(R_{i}+C_{j}\right)$ as the horizontal and $\left(R_{i}-C_{j}\right)$ as the vertical axis. $R_{i}+C_{j}$ measures the degree of importance of influential factors. $R_{i}-C_{j}$ explains the causal-effect relationship between the factors, that is a positive (negative) value for one factor means that it falls into the cause (effect) group. To highlight the interdependence of factors, significant relationships between them can be mapped on the cause-effect diagram using arrows. Note that Steps 1 to 6 are performed for both criteria and dimensions. In the following, assume $Z^{c}=\left[z_{i j}^{c}\right]_{m \times m} ; i, j=1, \ldots, m$ and $Z^{d}=\left[z_{k l}^{d}\right]_{n \times n} ; k, l=1, \ldots, n$ to be the crisp total relation matrix for criteria and dimensions, respectively.

Stage 2. Obtaining influential weights of each criterion and dimension.

Step 7. Obtain the unweighted super-matrix of dimensions. Based on the crisp total relation matrix $Z^{d}=\left[z_{k l}^{d}\right]_{n \times n}$ obtained from Step 5, the normalised matrix $N^{d}=\left[n_{k l}^{d}\right]_{n \times n}$ can be obtained as follows. 
$N^{d}=\left[\begin{array}{ccccc}z_{11}^{d} / d_{1} & \cdots & z_{1 l}^{d} / d_{1} & \cdots & z_{1 n}^{d} / d_{1} \\ \vdots & \ddots & \vdots & \ddots & \vdots \\ z_{k 1}^{d} / d_{i} & \cdots & z_{k l}^{d} / d_{i} & \cdots & z_{k n}^{d} / d_{i} \\ \vdots & \ddots & \vdots & \ddots & \vdots \\ z_{n 1}^{d} / d_{n} & \cdots & z_{n l}^{d} / d_{n} & \cdots & z_{n n}^{d} / d_{n}\end{array}\right]$

where

$d_{k}=\sum_{l=1}^{n} z_{k l}^{d}$

After normalisation, the unweighted super-matrix of dimensions, $W^{d}$ is derived by transposing $N^{d}$ as follows.

$$
W^{d}=\left[w_{k l}^{d}\right]_{n \times n}=\left(N^{d}\right)^{\prime}
$$

Step 8. Obtain the unweighted super-matrix of criteria. The crisp total relation matrix $Z^{c}=$ $\left[z_{i j}^{c}\right]_{m \times m}$ obtained from Step 5, includes $n \times n$ sub-matrices for $\mathrm{n}$ dimensions as follows.

$Z^{c}=\left(\tau^{k l}\right) \quad k, l=1, \ldots, n$

Where the sub-matrix $\tau^{k l}$ corresponds to the dimensions $k$ and $l$ and has $m_{k}$ rows and $m l$ columns and can be normalised in a similar way as in Step 7. Where the sub-matrix $\tau^{k l}$ has $m_{k}$ rows and $m_{l}$ columns, and includes the criteria of dimensions $k$ as its rows and the criteria of dimensions $l$ as its columns. The sub-matrix $\tau^{k l}$ can be normalised in a similar way as in Step 7. After normalisation of all sub-matrices, the normalised $N^{c}=\left[n_{i j}^{c}\right]_{m \times m}$ is obtained, and the unweighted super-matrix of criteria, $W^{c}$ is derived by transposing $N^{c}$ as follows.

$W^{c}=\left[w_{i j}^{c}\right]_{m \times m}=\left(N^{c}\right)^{\prime}$

Step 9. Calculate the weighted super-matrix. The weighted super-matrix is an $m \times m$ matrix $W=\left[w_{i j}\right]_{m \times m}$, in which the element $w_{i j}$, assuming that criterion $i$ belongs to dimension $k$ and criterion $j$ belongs to dimension $l$, can be calculated as follows.

$w_{i j}=w_{i j}^{c} \times w_{k l}^{d} \quad \forall c_{k i} \in D_{k}, c_{l j} \in D_{l}$

Step 10. Limit the weighted super-matrix. The super-matrix $W$ is multiplied by itself multiple times to obtain the limit weighted super-matrix to a fixed convergence value. The influential weights of each criterion can be obtained by $\lim _{g \rightarrow \infty} W^{g}$.

\section{Results}

To finalise the KSFs extracted from previous studies evaluation, a qualitative forecasting method, fuzzy-Delphi, is employed. To capture vagueness in data, this method was introduced by Ishikawa in 1993 to collect views and information related to a specific area (Hsu et al., 2010). Following step-wise process was carried out to reach finalised KSFs showing in Table 5, (i) 
based on fifty-five identified KSFs from literature review and a linguistic scale as Table $3_{\mathrm{a}}$, a structured questionnaire was compiled and circulated among 9 experts of the entrepreneurial food industry. The panel of experts is formed among the practitioners and managers of the food industry with the following conditions: (1) at least 10 years of experience in the food industry; (2) acting as chief executive officer (CEO) or chief supply chain officer (CSCO) of food companies for at least 5 years; (3) preferably having postgraduate (PG) education. The experts' profile is illustrated in Table 4.

\section{$\underline{\text { Insert Table } 4}$}

(ii) Assume the fuzzy number $\tilde{Z}_{i j}=\left(a_{i j}, b_{i j}, c_{i j}\right)$ to be the $j^{\text {th }} \mathrm{KSF}$ assessment of the $i^{\text {th }}$ expert of 9 experts (Bouzon et al., 2016), then fuzzy weights of KSFs $\tilde{a}_{i j}=\left(a_{j}, b_{j}, c_{j}\right)$ were computed as follows (Kumar et al., 2019).

$a_{j}=\min \left(a_{i j}\right)$

$b_{j}=\left(\prod_{i=1}^{n}\left(b_{i j}\right)\right)^{1 / n}$

$c_{j}=\max \left(c_{i j}\right)$

where $i=1,2,3, \ldots, 9, j=1,2,3, \ldots, 60$.

(iii) Expert's fuzzy inputs were defuzzified to obtain the crisp value of KSFs $S_{j}$ through computing an average of three numbers $a_{j}, b_{j}$ and $c_{j}$. For the final selection of the KSFs, a threshold value $\alpha=0.7$ based on consultation with experts and previous studies, is set if (i) If $S_{j} \geq 0.7$ accept the KSF; (ii) If $S_{j}<0.7$ reject it.

\section{Insert Table 5}

Each aforementioned expert was assigned approximately an hour to fill the online structured questionnaire. The experts were additionally asked to add any KSF which they think was required toward the formation of international collaboration in the entrepreneurial food industry. However, they did not recommend any other changes and were satisfied with the fuzzyDelphi method in finalising the KSFs. Therefore, eighteen KSFs, i.e. APF, I, PCO, TBP, OCD, ETE, K, CIF, L, Q/CPTM, ET, TR, EO, SCI, PCT, UMR, NPD, IMT are eventually finalised in this stage. The finalised KSFs were categorised into three dimensions of KSF through previous studies including $\left(\mathrm{D}_{1}\right)$ characteristics of effective development workers embraced PCO, TBP, Q/CPTM, ET, ETE, EO, L, and TR (Hines et al., 2010; Bombaywala and Riandita, 2015; Badraoui et al., 2020; Pearce et al., 2020), ( $\left.\mathrm{D}_{2}\right)$ communication, information, and resource sharing covered SCI, K, PCT, CIF, and APF (Suwannaporn and Speece, 2010; Habibah Abdul Talib et al., 2014; Taylor and Taylor 2015; Aschemann-Witzel et al., 2017; Long et al., 2018; 
Shankar et al., 2018), and ( $\left.\mathrm{D}_{3}\right)$ Marketing-related issues comprised UMR, NPD, and IMT (Suwannaporn and Speece, 2010; Kirkley, 2016; Shankar et al., 2018).

The implemented FDANP is described in the following. The assessment result of the group of three experts for the dimensions was gathered. To this end, a structured questionnaire involving two parts, the first and second parts related to the fuzzy DEMATEL and fuzzy ANP, respectively, was distributed among considered experts through a group online session. Each aforementioned expert was assigned approximately three hours to fill the structured questionnaire. Then, using linguistic variable and their corresponding TFNs in Table $3 \mathrm{~b}$, the fuzzy initial direct relation matrix is extracted. In the next steps, the normalised initial directrelation matrix and the total-relation matrix are calculated as shown in Tables $6 \mathrm{a}$ and $6 \mathrm{~b}$, respectively. In step 5, the CFCS method is conducted to get the defuzzified total relation matrix (see Table 6c). The decision-maker group set up a threshold (0.45) to filter out negligible relationships. The important relationships are shown in bold. Using the dataset $(\mathrm{R}+\mathrm{C})$ and $(\mathrm{R}-$ C) given in Table 6 , the causal diagram of the dimensions can be plotted as in Fig. 1. As shown in Fig. 1, $\mathrm{D}_{2}$ is the most important dimension having the highest $(\mathrm{R}+\mathrm{C})$ value. The rest of the dimensions are ranked as $\mathrm{D}_{3}$ and $\mathrm{D}_{1}$. Moreover, the dimensions were divided into clusters, namely cause cluster and effect cluster, based on $(\mathrm{R}-\mathrm{C})$ values. The cause cluster includes $\mathrm{D}_{1}$ with positive $(R-C)$ values, while the effect cluster is composed of $D_{2}$ and $D_{3}$ with negative ( $R$ $-\mathrm{C})$ values.

\section{Insert Table 6}

\section{Insert Figure 1}

Similar procedures (steps 1-6) are also applied for other KSFs. It turns out that IMT is the most important KSF having the highest $(\mathrm{R}+\mathrm{C})$ value. The rest of the KSFs are ranked as $\mathrm{L}$, PCO, SCI, TR, Q/CPTM, TBP, APF, PCT, K, ET, ETE, EO, CIF, UMR and NPD. Moreover, the cause KSFs include ETE, ET, EO, Q/CPTM, TR, L, PCO and TBP with positive (R - C) values, while the effect KSFs are composed of K, SCI, PCT, APF, IMT, UMR, CIF and NPD with negative $(\mathrm{R}-\mathrm{C})$ values. Based on the important relationships in bold given in Table 7, the impact relation map can be illustrated as in Fig. 2, which indicates the cause and effect relationship among the main KSFs.

\section{$\underline{\text { Insert Table } 7}$}

\section{Insert Figure 2}

Following steps 7 and 8 (ANP), the unweighted super-matrix of dimensions and the unweighted super-matrix of KSF are constructed. In step 9, the weighted matrix is calculated as shown in Table 8 by multiplying the matrices for the KSF and the dimensions. Finally, the weighted super-matrix is limited to get a long-term stable super-matrix.

\section{Insert Table 8}

Regarding the global influential weights of KSFs (see the last column of Table 8), IMT was the most important KSF with the highest weight $(0.167)$. The rest of the KSFs were 
prioritised as NPD, UMR, SCI, APF, CIF, PCT, K, PCO, TBP, L, TR, Q/CPTM, ET, ETE, and EO.

\section{Discussion and implications}

International collaboration is a crucial requirement of entrepreneurship. This collaboration seems so necessary in the food industry, which was considered a major contributor to environmental, social, and economic problems (Mazzucchelli et al., 2021). The requirement of a new food system in which entrepreneurs need to construct broadly collaboration has recently been argued (Lynde, 2020). Based on geographical conditions, different countries around the world have various capacities and potentialities in producing and trading food-related products. Therefore, forming international alliances and collaborations between entrepreneurs plays a vital role in the development of the food industry, particularly in an emerging economy (Sibbel, 2012; Erista et al., 2020; Lim and Antony, 2019; Jafari-Sadeghi et al., 2021b). Hence, investment in this specific field has been globally growing (Jafari-Sadeghi et al., 2021a).

A variety of studies have discussed the factors affecting international entrepreneurship (Zahra and Garvis, 2000; Jafari-Sadeghi et al., 2021d). However, precise study of the KSFs, a set of minimum capabilities to enter a competition, was essentially required for the food industry to form the international collaboration between entrepreneurs. This study was the first attempt to identify, map the causal relationship network, and prioritise the KSFs of international collaboration formation in the entrepreneurial food industry with a case study on Iran's emerging economy. In contrast to the relevant recent researches (see Table 1), this paper has simultaneously used qualitative and quantitative approaches, i.e. literature review and fuzzyDelphi, to extract and finalise the KSFs. As our reviewed literature reveals, previous researches have not applied a quantitative methodology grounded on multi-layer MCDM methods to attain the KSFs conceptual model even in other food industry issues. MCDM provides decision-makers with well-suited quantitative techniques to assess different problems in the presence of multiple, usually conflicting criteria (Garousi Mokhtarzadeh et al., 2020), same as this study. DEMATELANP is a multi-layer MCDM technique used in the current study. It has become a favorite methodology to investigate the KSFs of different issues (Mavi and Standing, 2018). Due to the high level of interdependencies between KSFs, our paper used DEMATEL-ANP to extract the conceptual model and weights of KSFs. In addition, to make the proposed model closer to the real world, the fuzzy version of DEMATEL-ANP was employed (Karuppiah et al., 2020). Thus, this research enhanced the reliability of the decision-making process by using fuzzy numbers to handle the vagueness and uncertainty of human judgments. According to cause and effect clusters, the extracted conceptual model illustrated that $\mathrm{D}_{1}$ is the cause factor among two other dimensions. In essence, $\mathrm{D}_{2}$ and $\mathrm{D}_{3}$ were casually affected by the personal and behavioral characteristics of entrepreneurs. In addition, according to the constructed model, $\mathrm{D}_{2}$ affected $\mathrm{D}_{1}$. Indeed, before any marketing-related activity is performed, it is required that two other mentioned dimensions were enhanced and empowered.

The constructed model provides a guiding framework of how to improve the KSFs of international collaboration in forming a more powerful alliance among international entrepreneurs of the food industry in the world. First of all, $\mathrm{D}_{2}$ is determined as the most 
important dimension. It is a reminder of the importance of the corresponding KSFs in the considered dimension. On the criteria level, the findings provide a valuable concern regarding the most important KSFs. IMT is known as the most important KSF. This KSF is impacted by a set of KSF; mainly belong to $\mathrm{D}_{1}$. Identification and forming an expert and trained entrepreneurship team with ETE is a key factor for a successful international collaboration. Therefore, at the outset of international collaboration for entrepreneurship, it is necessary to charter a project with qualified and capable team members that can carry out the collaboration. Having an EO is also a prerequisite of this team that can be measure as illustrated by (Govin and Wales, 2012; Langkamp Bolton and Lane, 2012). Beyond the above-mentioned technical and attitudinal characteristics, a PCO among team members is also necessary. All of the mentioned characteristics can be empowered and persuaded by leadership-style management to be applied by top management. The Q/CPTM also plays a leading role in other KSF. These features directly affect the SCI. The SCI KSF deals with issues related to sharing knowledge and information across supply chains. The necessity of sharing knowledge and information and enhancing the involvement and participation of supply chain different actors, e.g. suppliers, distributors, and retailers, is crucial for a successful international collaboration that is directly linked to features and capabilities of project team members. Without any doubt, marketing research is one of the required initial steps in an entrepreneurial international collaboration. Performing extensive and explanatory marketing research to extract the needs and tastes of customers in international markets can be achieved by having a professional and well-trained entrepreneurship team that can result in developing new products proportionate to international markets. The sequence of forming a professional team to perform or guide international market research and then developing a new product can be considered as an important foundation for a successful collaboration.

Organisations that seek to participate in an international entrepreneurial collaboration must initially be sure of their professional commitment and ability to lead this collaboration at an international level. Therefore, this research attempted to develop a conceptual model of the main KSFs of international collaboration formation in the entrepreneurial food industry for both senior managers and international entrepreneurs to successfully make decisions as well as performing in international collaboration formation. This model can additionally facilitate the task of managers in an initial and advanced type of decisions to form international collaboration. As a result, availability and ability of continuous financing on different functions, e.g. UMR, NPD, etc. are also needed to be assured at the beginning of the collaboration. Otherwise, there is a great possibility of failure. Therefore, it can be proposed that before entering any international collaboration in the entrepreneurial food industry, participants initially approve their minimum capability of providing required financial sources. Then, appraising and selecting appropriate partners based on their team member capabilities, entrepreneurial orientation, and financial abilities are necessitated. Forming the international collaboration team, performing comprehensive market research to guide NPD is another KSF of this collaboration.

\section{Conclusion and future recommendation}

While a variety of studies discussed the factors affecting international entrepreneurship,

this study filled the gap of proposing a conceptual framework and prioritising the KSFs of international collaboration formation in the entrepreneurial food industry with a case study on 
Iran's emerging economy. After the identification of KSFs through previous studies, the main KSFs were finalised with aid of a fuzzy-Delphi method based on experts group opinion. The main selected KSFs then are modelled using an FDANP methodology. Following experts' opinion, the fuzzy DEMATEL technique was applied to construct an influential network relationship of KSFs, where the fuzzy ANP was used to prioritise them. The high-scored KSFs were determined to facilitate international collaboration formation in the entrepreneurial food industry.

The novelty of this study could be developed in future researches by employing other KSF extraction approaches, e.g. multiple case studies, in-depth interview, etc. in place of literature review. New uncertain approaches, e.g. hesitant fuzzy, intuitionistic fuzzy, interval fuzzy, and interval-valued intuitionistic fuzzy, etc. instead of fuzzy numbers are applicable also. Moreover, other causal relationship analysis, weighing, and prioritising methods, e.g. ISM, MICMAC, AHP, etc. could be applied and compared with this paper. Furthermore, this framework was designed for Irans' emerging economy and is redesignable for other emerging economies or developed economies to benchmark the outputs. Identification of KSFs in entrepreneurial collaboration among developed countries or between developed countries on one side and emerging economies on another side can be proposed. Also, evaluating the success of international collaborations and extracting the contribution of the identified KSFs can be considered. Furthermore, researchers can develop models to approximate the possibility or chance of success in international collaboration based on the KSFs. Ultimately, this paper has used the opinion of 9 relevant experts, future researches can expand the experts participated. Besides, this framework is recommended to be performed in other industries in future researches.

\section{References}

Aggarwal, S., and Srivastava , M. (2016), "Towards a grounded view of collaboration in Indian agri-food supply chains: a qualitative investigation", British Food Journal, 118(5), 1085-1106.

Ahadi, S., and Kasraie, S. (2020), "Contextual factors of entrepreneurship intention in manufacturing SMEs: the case study of Iran", Journal of Small Business and Enterprise Development, 27, 633-657.

Ali, J., Kapoor, S., and Moorthy, J. (2010), "Buying behaviour of consumers for food products in an emerging economy", British Food Journal, 112, 109-124.

Aschemann-Witzel, J., Hooge, I., Rohm, H., Normann, A., Bossle, M., Grønhøj, A., and Oostindjer, M. (2017), "Key characteristics and success factors of supply chain initiatives tackling consumer-related food waste e A multiple case study", Journal of Cleaner Production, 155, 33-45.

Aschemann-Witzel, J., Perez-Cueto, F., Niedzwiedzka, B., Verbeke, W., and Bech-Larsen, T. (2012), "Transferability of private food marketing success factors to public food and health policy: An expert Delphi survey", Food Policy, 37, 650-660.

Badraoui, I., Vorst, J., and Boulaksil, Y. (2020), "Horizontal logistics collaboration: an exploratory study in Morocco's agri-food supply chains", International Journal of Logistics Research and Applications, 23(1), $85-102$.

Blažková, I., and Dvouletý, O. (2019), "Investigating the differences in entrepreneurial success through the firmspecific factors Microeconomic evidence from the Czech food industry", Journal of Entrepreneurship in Emerging Economies, 11, 154-176.

Bombaywala, M., and Riandita, A. (2015), "Stakeholders' Collaboration on Innovation in Food Industry", Procedia - Social and Behavioral Sciences. 169, pp. 395 - 399. Elsevier.

Boudlaie, H., Mahdiraji, H. A., Shamsi, S., Jafari-Sadeghi, V., and Garcia-Pereze, A. (2020), "Designing a human resource scorecard: An empirical stakeholder-based study with a company culture perspective", Journal of Entrepreneurship, Management and Innovation, 16(4), 113-147. 
Bouzon, M., Govindan, K., Taboada Rodriguez, C., and Campos, L. (2016), "Identification and analysis of reverse logistics barriers using fuzzy Delphi method and AHP", Resources, Conservation and Recycling, 108, 182197.

Bruton, G., Ahlstrom, D., and Obloj, K. (2008), "Entrepreneurship in Emerging Economies: Where Are We Today and Where Should the Research Go in the Future", Entrepreneurship theory and practic, 1-14.

Chen, I.S., (2016), "A combined MCDM model based on DEMATEL and ANP for the selection of airline service quality improvement criteria: A study based on the Taiwanese airline industry", Journal of Air Transport Management, 57, 7-18.

Dağdeviren, M., and Yüksel, İ. (2010), "A fuzzy analytic network process (ANP) model for measurement of the sectoral competititon level (SCL)", Expert Systems with Applications, 37(2), 1005-1014.

Dalalah, D., and Bataineh, O. (2009), "A fuzzy logic approach to the selection of the best silicon crystal slicing technology", Expert Systems with Applications, 36(2), 3712-3719.

Dinçer, H., Dinçer, S., and Martínez, L. (2019), "Interval type 2-based hybrid fuzzy evaluation of financial services in E7 economies with DEMATEL-ANP and MOORA methods", Applied Soft Computing, 79, 186-202.

Dung, T., Bonney, L., Adhikari, R., and Miles, M. (2020), "Entrepreneurial orientation, knowledge acquisition and collaborative performance in agri-food value-chains in emerging markets", Supply Chain Management, 25(5), 521-533.

Erista, I., Andadari, R., Usmanij, P., and Ratten, V. (2020), The Influence of Entrepreneurship Orientation on Firm Performance: A Case Study of the Salatiga Food Industry, Indonesia. Ratten: Entrepreneurship as Empowerment: Knowledge Spillovers and Entrepreneurial Ecosystems.

Fearne, A., and Hughes , D. (1999), "Success factors in the fresh produce supply chain: insights from the UK", Supply Chain Management, 4, 120-131.

Figuié, M., and Moustier, P. (2009), "Market appeal in an emerging economy: Supermarkets and poor consumers in Vietnam", Food Policy, 210-217.

Flammini, S., Arcese, G., Lucchetti, M., and Mortara, L. (2017), "Business model configuration and dynamics for technology commercialization in mature markets", British Food Journal, 119, 2340-2358.

Fotopoulos, C., Psomas, E., and Vouzas, F. (2010), "ISO 9001:2000 implementation in the Greek food sector", The TQM Journal, 22(2), 129-142.

Garousi Mokhtarzadeh, N., Amoozad Mahdiraji, H., Jafari-Sadeghi, V., Soltani, A., and Abbasi Kamardi, A. (2020), "A product-technology portfolio alignment approach for food industry: a multi-criteria decision making with z-numbers", British Food Journal, 122(12), 3947-3967.

Gien, L., Taylor, S., Barter, K., Tiep, N., Mai, B., and Lan, N. (2007), "Poverty reduction by improving health and social services in Vietnam", Nursing and Health Sciences, 9(4), 304-309.

Govin, J., and Wales, W. (2012), "The measurement of entrepreneurial orientation", Entrepreneurship Theory and Practice, 36(4), 677-702.

Habibah Abdul Talib, H., Anuar Mohd Ali, K., and Idris, F. (2014), "Critical success factors of quality management practices among SMEs in the food processing industry in Malaysia", Journal of Small Business and Enterprise Development, 21, 152-176.

Hines, A., Cohen, E., Tran, T., Lee, P., and Phu, L. (2010), "The Development of Social Work in Vietnam: The Role of International Collaboration", Social Work Education: The International Journal, 29(8), 910-922.

Hsu, Y., Lee, C., and Kreng, V. (2010), "The application of Fuzzy Delphi Method and Fuzzy AHP in lubricant regenerative technology selection", Expert Systems with Applications, 37(1), 419-425.

Hutahayan, B. (2019), "Factors affecting the performance of Indonesian special food SMEs in entrepreneurial orientation in East Java", Asia Pacific Journal of Innovation and Entrepreneurship, 13, 231-246.

Jack, C., Anderson, D., and Connolly, N. (2014), "Innovation and skills: implications for the agri-food sector", Education and Training, 56, 271-286.

Jafari-Sadeghi, V., Sukumar, A., Pagán-Castaño, E., and Dana, L. P. (2021a), "What drives women towards domestic vs international business venturing? An empirical analysis in emerging markets", Journal of Business Research, 134, pp. 647-660.

Jafari Sadeghi, V., and Biancone, P. (2019), "International entrepreneurship by particular people 'on their own terms': a study on the universal characteristics of entrepreneurs in evolving economies", International Journal of Entrepreneurship and Small Business, 37, pp. 288-308. 
Jafari-Sadeghi, V., Mahdiraji, H. A., and Dana, L. P. (2021b), "Empirical International Entrepreneurship", Springer, London.

Jafari-Sadeghi, V., Garcia-Perez, A., Candelo, E., and Couturier, J. (2020), "Exploring the impact of digital transformation on value creation through technology entrepreneurship: Role of technology readiness, exploration and exploitation", Journal of Business Research, 100, pp. 100-111.

Jafari-Sadeghi, V., Mahdiraji, H. A., and Dana, L. P. (2021d), "Introduction: International Entrepreneurship from Methodological Perspectives", In Empirical International Entrepreneurship (pp. 1-6), Springer, Cham.

Jafari-Sadeghi, V., Mahdiraji, H. A., Bresciani, S., and Pellicelli, A. C. (2021c), "Context-specific microfoundations and successful SME internationalisation in emerging markets: A mixed-method analysis of managerial resources and dynamic capabilities", Journal of Business Research, 134, pp. 352-364.

Keast, R., Mandell, M., and Agranoff, R. (2014), Network Theory in the Public Sector: Building New Theoretical Frameworks. New York: Routledge.

Ketelhöhn, W. (1998), "What is a key success factor?", European Management Journal, 16(3), 335-340.

Khalilzadeh, M., Shakeri, H., and Zohrehvandi, S. (2021), "Risk identification and assessment with the fuzzy DEMATEL-ANP method in oil and gas projects under uncertainty", Procedia Computer Science, 181, 277284.

Khan, S., Mubarik, M., Kusi-Sarpong, S., Zaman, S., and Kazmi, S. (2020), "Social sustainable supply chains in the food industry: A perspective of an emerging economy", Corporate Social Responsibility and Environmental Management, 404-418.

Kirkley, W. (2016), "Creating ventures: decision factors in new venture creation", Asia Pacific Journal of Innovation and Entrepreneurship, 10, 151-167.

Knudson, W., Wysocki, A., Champagne, J., and Peterson, H. (2004), "Entrepreneurship and Innovation in the AgriFood System", American Journal of Agricultural Economics, 86, 1330-1336.

Kumar, A., Zavadskas, E., Mangla, S., Agrawal, V., Sharma, K., and Gupta, D. (2019), "When risks need attention: adoption of green supply chain initiatives in the pharmaceutical industry", International Journal of Production Research, 57(11), 3354-3576.

Langkamp Bolton, D., and Lane, M. (2012), "Individual entrepreneurial orientation: development of a measurement instrument", Education and Training, 54(2/3), 219-233.

Li, J.H., Yu, W.J., Lai, Y.H., and Ko, Y.C. (2012), "Major food safety episodes in Taiwan: Implications for the necessity of international collaboration on safety assessment and management", Kaohsiung Journal of Medical Sciences, S10-S16.

Liang, H., Ren, J., Gao, Z., Gao, S., Luo, X., Dong, L., and Scipioni, A. (2016), "Identification of critical success factors for sustainable development of biofuel industry in China based on grey decision-making trial and evaluation laboratory (DEMATEL)", Journal of Cleaner Production, 131, 500-508.

Liao, S.K., and Chang, K.L. (2009), "Select televised sportscasters for Olympic Games by analytic network process", Management Decision, 47(1), 14-23.

Lim, S. A., and Antony, J. (2019), "Food Industry and its Contribution to the Global Economy. In S. Lim, and J. Antony", Statistical Process Control for the Food Industry: A Guide for Practitioners and Managers (pp. 13-21), Wiley.

Long, T., Looijen, A., and Blok, V. (2018), "Critical success factors for the transition to business models for sustainability in the food and beverage industry in the Netherlands", Journal of Cleaner Production, 175, pp. 82-95.

Lynde, R. (2020), "Innovation and entrepreneurship driving food system transformation", Physiology and Behavior, $220,112866$.

Mahdiraji, H. A., Hafeez, K., Kamardi, A. A. A., and Garza-Reyes, J. A. (2021), "Evaluating key capabilities for developing global collaborative networks using a multi-layer decision-making approach", Industrial Management and Data Systems.

Mahmoudi, S., Jalali, A., Ahmadi, M., Abasi, P., and Salari, N. (2019), "Identifying critical success factors in Heart Failure Self-Care using fuzzy DEMATEL method", Applied Soft Computing, 84, 105729.

Mavi, R., and Standing, C. (2018), "Critical success factors of sustainable project management in construction: A fuzzy DEMATEL-ANP approach", Journal of Cleaner Production, 194, 751-765. 
Mazzucchelli, A., Gurioli, M., Graziano, D., Quacquarelli, B., and Aouina-Mejri, C. (2021), "How to fight against food waste in the digital era: Key factors for a successful food sharing platform", Journal of Business Research, 124, 47-58.

Nagpal, S., Kumar, A., and Khatri, S. (2017), "Modeling interrelationships between CSF in ERP implementations: total ISM and MICMAC approach", International Journal of System Assurance Engineering and Management, 8(4), 782-798.

Napier, N., Harvey, M., and Usui, K. (2008), "Management Education in Emerging Economies: The Impossible Dream?", Journal of Management Education, 32(6), 792-816.

Ogden, S., and Grigg, N. (2003), "The development of sector-based quality assurance standards in the UK: diverging or dovetailing?", The TQM Magazine, 15(1), 7-13.

Opricovic, S., and Tzeng, G. (2003), "Defuzzification within a multicriteria decision model", International Journal of Uncertainty, Fuzziness and Knowledge-Based Systems, 11(5), 635-652.

Pearce, T., Antonelli, A., Brearley, F., Couch, C., Forzza, R., Gonçalves, S., Breman, E. (2020), "International collaboration between collections-based institutes for halting biodiversity loss and unlocking the useful properties of plants and fungi", Plants, People, Planet, 2(5), 515-534.

Petruzzelli, A., and Svejenova, S. (2016), "Cooking up New Ideas across Levels and Contexts: Introduction to the Special Issue on Innovation and Entrepreneurship in the Food Industry", Industry and Innovation, 22, 655659.

Pilar, E., and Bongo, I. (2019), "Structural relationships among critical failure factors of microbusinesses", Journal of Small Business and Enterprise Development, 27(1), pp. 148-174.

Rey-Martí, A., Ribeiro-Soriano, D., and Palacios-Marqués, D. (2016), "Entrepreneurial attributes of human capital and contingency factors in the culinary tourism", International Entrepreneurship and Management Journal, 12(1), 67-85.

Rezaei, S., Dana, L.-P., and Ramadani, V. (2017), Introduction to Iranian Entrepreneurship. Cham: Springer.

Saaty, T. (1996), Decision making with dependence and feedback: The analytic network process. Pittsburgh: RWS publications.

Salehi, R., Asaadi, M., Rahimi, M., and Mehrabi, A. (2020), "The information technology barriers in supply chain of sugarcane in Khuzestan province, Iran: A combined ANP-DEMATEL approach", Information Processing in Agriculture.

Shankar, R., Gupta, R., and Pathak, D. (2018), "Modeling critical success factors of traceability for food logistics system", Transportation Research Part E: Logistics and Transportation Review, 119, 205-222.

Sharma, Y., Yadav, A., Mangla, S., and Patil, P. (2018), "Ranking the Success Factors to Improve Safety and Security in Sustainable Food Supply Chain Management Using Fuzzy AHP", Materials Today: Proceedings, 5(5), 12187-12196.

Sibbel, A. (2012), "Public nutrition and the role of the food industry", British Food Journal, 114, 784-797.

Suwannaporn, P., and Speece, M. (2010), "Assessing new product development success factors in the Thai food industry", British Food Journal, 112, 364-386.

Tajvidi, R., and Tajvidi, M. (2020), "The growth of cyber entrepreneurship in the food industry: virtual community engagement in the COVID-19 era", British Food Journal.

Taylor, E., and Taylor, J. (2015), "Improving food safety -replicating the Abu Dhabi success story", Worldwide Hospitality and Tourism Themes, 7, 90-96.

Ullah, F., Sepasgozar, S., Jamaluddin Thaheem, M., Wang, C., and Imran, M. (2021), "It's all about perceptions: A DEMATEL approach to exploring user perceptions of real estate online platforms", Ain Shams Engineering Journal.

Whitmore, E., and Wilson, M. (1997), "Accompanying the process: social work and international development practice", International Social Work, 40(1), 57-74.

Yaseen, A., Saleem, M., Zahra, S., and Israr , M. (2018), "Precursory effects on entrepreneurial behaviour in the agri-food industry", Journal of Entrepreneurship in Emerging Economies, 10, 2-22.

Zahra, S., and Garvis, D. (2000), "International corporate entrepreneurship and firm performance: The moderating effect of international environmental hostility", Journal of Business Venturing, 15, 469-492. 


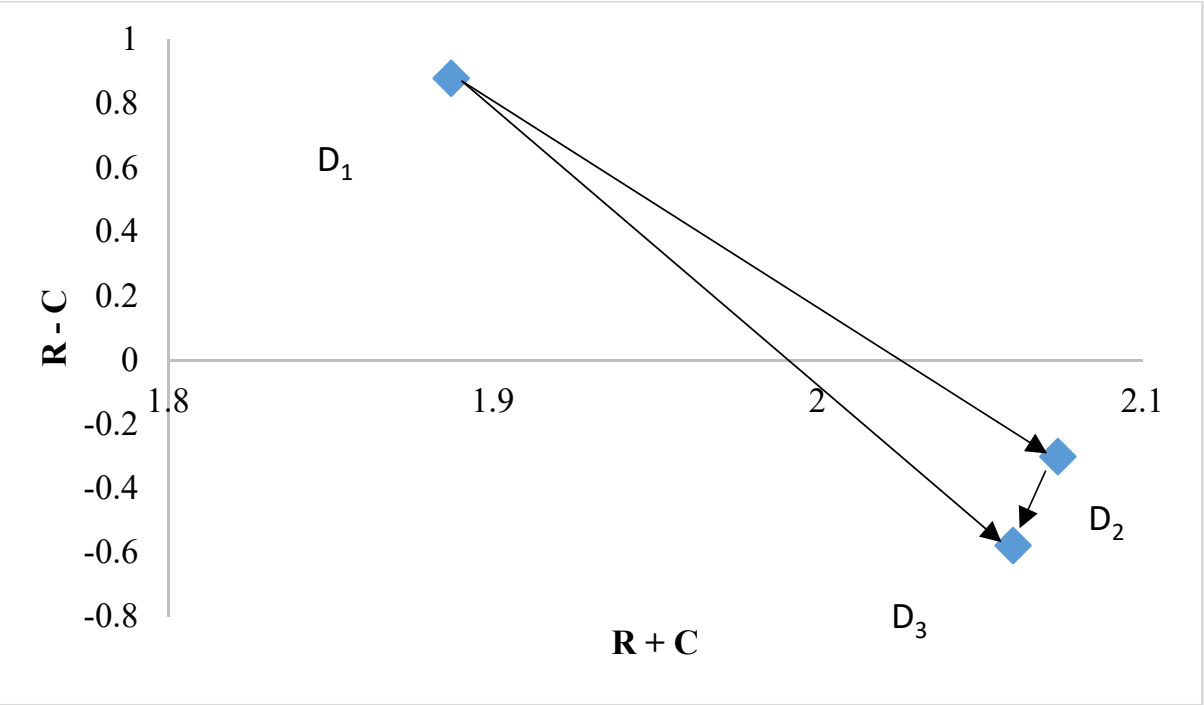

Figure 1. The causal diagram of the dimensions 


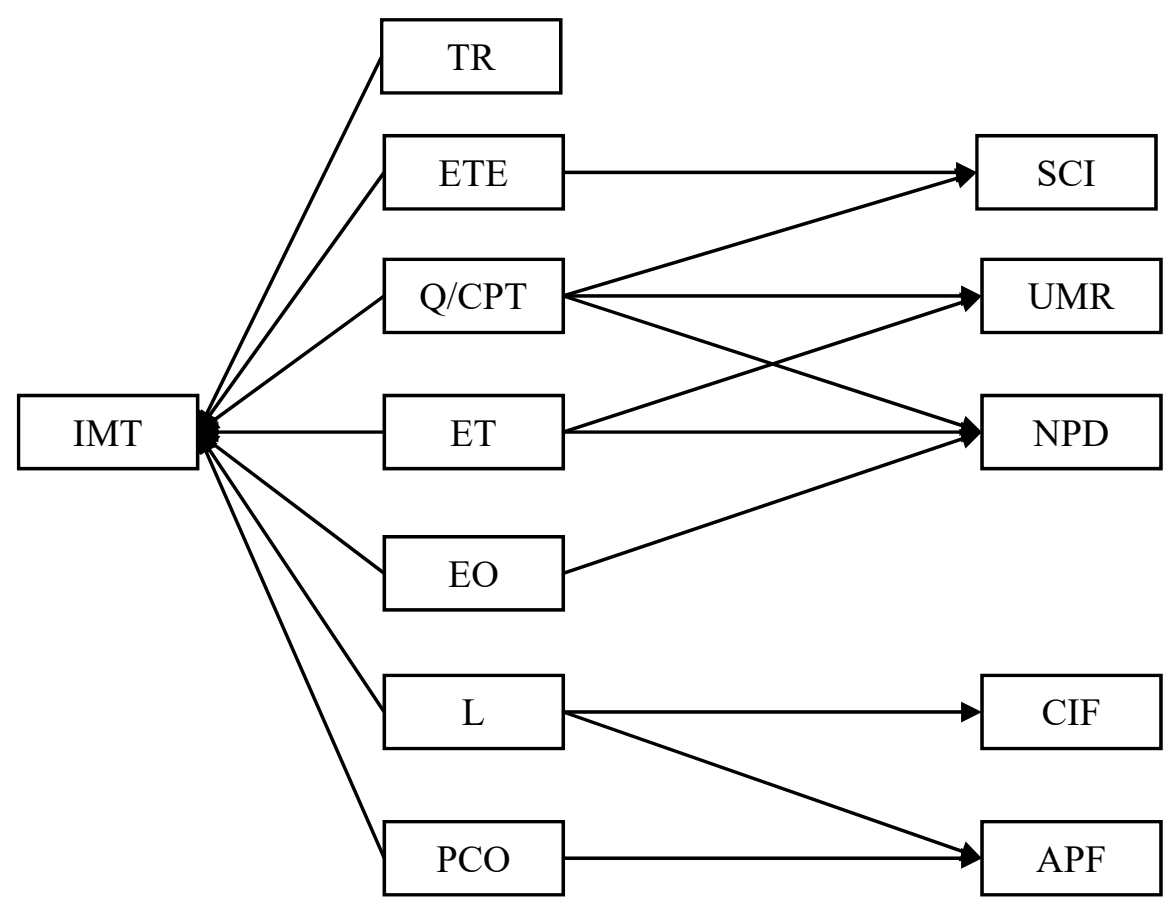

Figure 2. The impact relation map for main KSF 
Table 1. A literature review of recent researches employed KSF theory in the food industry

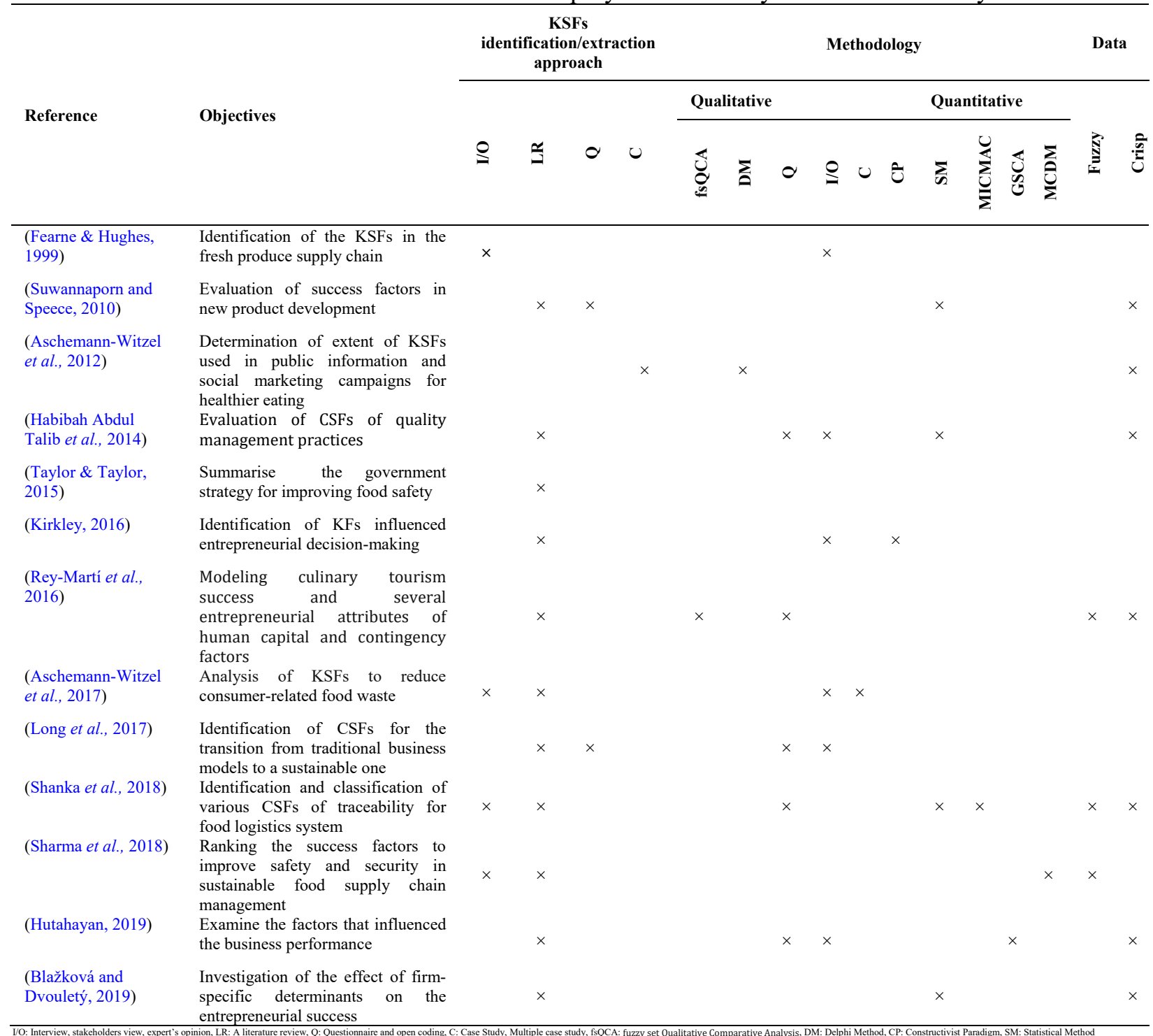


Table 2. List of KSF extracted from literature review

\begin{tabular}{|c|c|c|}
\hline KSFs & Description & References \\
\hline Firm Size (FS) & $\begin{array}{l}\text { Size of firm and number of employees. It determines the economies of scale and also the effects of } \\
\text { differences in technology and investment opportunities }\end{array}$ & $\begin{array}{l}\text { (Rey-Martí et al., 2016; Blažková } \\
\text { and Dvouletý, 2019) }\end{array}$ \\
\hline Firm Location (FL) & The right place and possibilities of the place are connected to start the initiative & $\begin{array}{l}\text { (Aschemann-Witzel et al., 2017; } \\
\text { Rey-Martí et al., 2016) }\end{array}$ \\
\hline Firm Age (FA) & $\begin{array}{l}\text { The competence building requires time; thus, it is plausible to assume that firm age is associated } \\
\text { with knowledge accumulated by firms, which may cause higher returns. }\end{array}$ & (Blažková and Dvouletý, 2019) \\
\hline $\begin{array}{l}\text { A Clear Narrative and } \\
\text { Vision }(\mathrm{CNV})\end{array}$ & It is a Motivation for successful partnerships and customer engagement efforts & (Long et al., 2017) \\
\hline Business Strategies (BS) & $\begin{array}{l}\text { It means corporate planning including structure, process management, RBV strategies, generic } \\
\text { strategies, functional level strategies, and new product strategy and planning }\end{array}$ & $\begin{array}{l}\text { (Hutahayan, 2019; Habibah } \\
\text { Abdul Talib et al., 2014; Kirkley, } \\
\text { 2016; Suwannaporn and Speece, } \\
\text { 2010) }\end{array}$ \\
\hline Timing (TI) & $\begin{array}{l}\text { It means being the first initiative to raise attention to the food-related issues or starting the } \\
\text { initiative at the moment that these issues became a topicality in society }\end{array}$ & (Aschemann-Witzel et al., 2017) \\
\hline Knowledge (K) & It refers to the significance of accumulating knowledge & (Aschemann-Witzel et al., 2017) \\
\hline Positive Focus (PF) & $\begin{array}{l}\text { It provides adequate focus on how to ensure food is eaten and used humorously or to underline the } \\
\text { value of foods }\end{array}$ & (Aschemann-Witzel et al., 2017) \\
\hline Multiple Aims (MA) & It refers to the initiative aimed at multiple goals at the same time & (Aschemann-Witzel et al., 2017) \\
\hline $\begin{array}{l}\text { Attention Management } \\
(\mathrm{AM})\end{array}$ & It means getting (media) attention at the right moments in time not 'overdoing' it & (Aschemann-Witzel et al., 2017) \\
\hline $\begin{array}{l}\text { A Large Scale of } \\
\text { Operations (LSO) }\end{array}$ & $\begin{array}{l}\text { It means either becoming a big (in terms of size) initiative (or campaign) or being able to work on } \\
\text { a long-term basis }\end{array}$ & (Aschemann-Witzel et al., 2017) \\
\hline Volume Growth (VG) & It refers to fund the necessary investments and provide a degree of confidence in the future & (Fearne and Hughes, 1999) \\
\hline $\begin{array}{l}\text { Availability of both } \\
\text { appropriate partners and } \\
\text { funding (APF) }\end{array}$ & It refers to genuine partnerships and funding from private or government sources. & (Napier et al., 2008) \\
\hline $\begin{array}{l}\text { Continuous Investment } \\
\text { and Funding (CIF) }\end{array}$ & It means not increasingly tight margins. Funding from private or government sectors & $\begin{array}{l}\text { (Aschemann-Witzel et al., 2017; } \\
\text { Fearne \& Hughes, 1999) }\end{array}$ \\
\hline $\begin{array}{l}\text { Capital Structure and } \\
\text { Profitability (CSP) }\end{array}$ & It indicates how validity is needed to realise sustainable outcomes and impacts & $\begin{array}{l}\text { (Long et al., 2017; Blažková and } \\
\text { Dvouletý, 2019) }\end{array}$ \\
\hline Leadership (L) & It means top management commitment is a critical factor to perform programs & $\begin{array}{l}\text { (Habibah Abdul Talib, et al., } \\
\text { 2014) }\end{array}$ \\
\hline $\begin{array}{l}\text { Good Staff or the } \\
\text { Individuals }(\mathrm{GS} / \mathrm{I})\end{array}$ & $\begin{array}{l}\text { Capable of driving the process of innovation and develop good trading relationships with key } \\
\text { customers. Also, It refers to demographics, i.e., age, gender of entrepreneurs, education, ethnicity, } \\
\text { having knowledge and experience, entrepreneurial parents or family background as regards } \\
\text { entrepreneurship, network, and contacts }\end{array}$ & $\begin{array}{l}\text { (Fearne and Hughes, 1999; } \\
\text { Kirkley, 2016; Rey-Martí et al., } \\
\text { 2016) }\end{array}$ \\
\hline $\begin{array}{l}\text { Personal characteristics } \\
(\mathrm{PCH})\end{array}$ & It refers to personal attributes and means effective development workers & (Gien et al., 2007) \\
\hline $\begin{array}{l}\text { Quality/Capability of } \\
\text { Project Team Members } \\
\text { (Q/CPTM) }\end{array}$ & It means knowledge and skills of the team members are an important item of being successful & (Taylor \& Taylor, 2015) \\
\hline $\begin{array}{l}\text { Enough technical } \\
\text { expertise (ETE) }\end{array}$ & $\begin{array}{l}\text { It means technical expertise amongst food manufacturers, the requirement for legal framework, } \\
\text { and difficulty in predicting future needs. }\end{array}$ & (Bombaywala \& Riandita, 2015) \\
\hline $\begin{array}{l}\text { Teamwork and flexibility } \\
\text { (TF) }\end{array}$ & $\begin{array}{l}\text { It describes how team members need to be mature, flexible, pro-active, tenacious, and high } \\
\text { creative to reach alternative solutions and to deal with the complexity and unpredicted challenges. }\end{array}$ & $\begin{array}{l}\text { (Gien et al., 2007; Whitmore \& } \\
\text { Wilson, 1997) }\end{array}$ \\
\hline $\begin{array}{l}\text { Entrepreneurial Team } \\
\text { (ET) }\end{array}$ & $\begin{array}{l}\text { A talented team of specialists, suitably qualified and experienced personnel to facilitate the } \\
\text { development and distribution of innovative products and services }\end{array}$ & (Kirkley, 2016) \\
\hline $\begin{array}{l}\text { Professional commitment } \\
\text { (PCO) }\end{array}$ & $\begin{array}{l}\text { It means loyalty, the desire to stay in a profession, and a sense of responsibility toward the } \\
\text { profession's special challenges i.e. effective relationships. }\end{array}$ & $\begin{array}{l}\text { (Gien et al., 2007; Whitmore \& } \\
\text { Wilson, 1997) }\end{array}$ \\
\hline $\begin{array}{l}\text { Trust between partners } \\
\text { (TBP) }\end{array}$ & It refers to confidence and professional respect within and between partners. & $\begin{array}{l}\text { (Bombaywala and Riandita 2014; } \\
\text { Badraoui et al., 2020; Pearce et } \\
\text { al., 2020) }\end{array}$ \\
\hline Interdependence (I) & It refers to close relationships between partners & (Keast et al., 2014) \\
\hline
\end{tabular}

Interdependence (I)

Keast et al., 2014) 


\begin{tabular}{|c|c|}
\hline KSFs & Description \\
\hline $\begin{array}{l}\text { Overcoming cultural } \\
\text { differences }(\mathrm{OCD})\end{array}$ & $\begin{array}{l}\text { It refers to minimising misunderstandings and frustration by forming a team that effort to } \\
\text { understand the history, political, economic, and cultural context of the partner country. }\end{array}$ \\
\hline Training (TR) & $\begin{array}{l}\text { It is emphasised on both pieces of training of the business owner or entrepreneur associated with } \\
\text { competencies and skills in a specific sector, industry or product area, and human capital. }\end{array}$ \\
\hline $\begin{array}{l}\text { Business Performance } \\
\text { (BP) }\end{array}$ & It indicates Marketing and financial performance, sales growth, profit, assets, and market share \\
\hline Productivity (P) & $\begin{array}{l}\text { It refers to labor productivity which is understood as a key factor of firm performance due to its } \\
\text { positive impacts on cost. }\end{array}$ \\
\hline $\begin{array}{l}\text { Improvement of } \\
\text { Measurement and Control } \\
\text { of Costs (IM/CC) }\end{array}$ & It means the pursuit of further gains in efficiency \\
\hline $\begin{array}{l}\text { Human Resource } \\
\text { Management (HRM) }\end{array}$ & $\begin{array}{l}\text { Human resources are strategic capital; employee empowerment is such an essential practice to } \\
\text { enter a competitive market }\end{array}$ \\
\hline $\begin{array}{l}\text { Company Experience and } \\
\text { Competencies (CEC) }\end{array}$ & $\begin{array}{l}\text { It emphasises on company's competency and experience in new product development, educational } \\
\text { background, networking competencies, long-standing experience with information and } \\
\text { competence building }\end{array}$ \\
\hline Branding (B) & $\begin{array}{l}\text { It is mentioned as a good name of a firm or product. Brand image is an item that consumers tend } \\
\text { to pose a lot of trust in it and the company should ensure that the items sold under their brands are } \\
\text { genuine and of desired quality }\end{array}$ \\
\hline Technological & Consideration of the rapidly changing technology environment and also information technology to \\
\hline
\end{tabular}

Continual Innovation (CI)

Entrepreneurial

Orientation (EO)

Strategic

Communication issues

$(\mathrm{SCI})$

Proper Coordination and Transparency (PCT)

Logistics

Competitiveness (LC)

Use of Transportation Technology (UTT)

Effective Transportation Management (ETM)

Marketing-Related Issues (MRI)

Media Coverage (MC)

Business Opportunity (BO)

International Benchmarking (IB)

Customer Focus (CF)

Packaging (PAC)

Environmental Dynamics and Socio-Demographics Factors $(\mathrm{ED} / \mathrm{SDF})$

Risk Analysis (RA)
It means novelty of the idea which is a driver of pushing firms to fulfill as many sustainability aspects as possible, innovative service level, and relationships with key customers

It emphasises innovative, proactive, and risk-taking processes, practices, and decision-making that lead to new input

It refers to such items related to communication including 1) Internal and external interface/communication and knowledge/information sharing throughout supply chain 2) external linkages and collaboration with other organisations or supply chain actors, particularly with suppliers 3 ) consultation and engagement with stakeholders 4) extensive industry involvement

It is associated with proper coordination and information exchange system among all stakeholders which leads to visibility of the origin and history of products and more transparency. Transparency means openness and communication

It refers to the necessity of competition at local and global levels to survive in such a competitive market

It indicates the significance of information management and integrating information flow at all stages of the supply chain

It emphasises reducing information asymmetries which leads to reduce in various costs related to procurement, inventory, logistics, distribution, and an increase in product quality and transparency among processes which further results in consumer satisfaction.

It refers to such items related to market and competition including 1) use of marketing research (UMR) for customer information 2) pricing and market price stability (P/MPS) which leads to lesser bullwhip effect and improved coordination 3) advertising, promotion, and marketing activity (AP) 4) sensory evaluation in new product development (NPD) 5) better market accessibility and Prevailing market conditions (BMA) 6) increased marketing and trading (IMT) 7) identification of need/problem and market demand

Social media is easily available; companies can share challenges and important issues of the food industry, e.g., food waste topics, via social media

It has appeared when the competitive advantage is in harmony with a specific situation

International trend awareness is a critical factor to internationalise entrepreneurship

It is related to customer demand, consumer-targeted, consumer's satisfaction, and positive link with customer orientation

It is used to enhance food security and safety and also minimises the risk of contamination

It is related to the significance of consideration of resources and constraints in the environment, i.e., external events that are beyond the wider environment such as the influence of regulation or consumer trends, demographical and environmental conditions which affect the security of food as the population is increasing day by day the demands for food is also increased, environmental uncertainty and competitive level

It is associated with risk management strategies in the food supply chain including in-depth research to identify specific risks and challenges
References

(Gien et al., 2007; Whitmore and Wilson, 1997)

(Rey-Martí, et al., 2016)

(Hutahayan, 2019)

(Blažková and Dvouletý, 2019)

(Fearne \& Hughes, 1999)

(Habibah Abdul Talib et al., 2014)

(Aschemann-Witzel et al., 2017; Suwannaporn and Speece, 2010)

(Aschemann-Witzel et al., 2017; Shankar et al., 2018)

(Kirkley, 2016; Sharma et al., 2018)

(Long et al., 2017; Fearne and Hughes, 1999; Kirkley, 2016)

(Hutahayan, 2019)

(Long et al., 2017; AschemannWitzel et al., 2017; Suwannaporn and Speece, 2010; Habibah Abdul Talib, et al., 2014; Taylor and Taylor, 2015)

(Shankar et al., 2018)

(Shankar et al., 2018)

(Shankar et al., 2018; Habibah Abdul Talib et al., 2014)

(Shankar et al., 2018; Habibah Abdul Talib et al., 2014)

(Suwannaporn and Speece, 2010; Kirkley, 2016; Shankar et al., 2018)

(Aschemann-Witzel et al., 2012)

(Aschemann-Witzel et al., 2012)

(Aschemann-Witzel et al., 2012; Taylor and Taylor, 2015)

(Aschemann-Witzel et al., 2017; Habibah Abdul Talib et al., 2014; Shankar et al., 2018) (Sharma et al., 2018)

(Long et al., 2017; Hutahayan, 2019; Kirkley, 2016; Sharma et al., 2018)

(Taylor and Taylor, 2015; Shankar et al., 2018; Sharma et al., 2018) 


\begin{tabular}{|c|c|c|}
\hline KSFs & Description & References \\
\hline $\begin{array}{l}\text { Consideration } \\
\text { Sustainability (CS) }\end{array}$ & $\begin{array}{l}\text { Sustainability has become the key focus of top management and researchers; as it leads to making } \\
\text { an organisation more competitive in the market, integration of sustainability throughout a business } \\
\text { is a KSF }\end{array}$ & $\begin{array}{l}\text { (Shankar et al., 2018; Long et } \\
\text { al., 2017) }\end{array}$ \\
\hline $\begin{array}{l}\text { Safe and Quality Food } \\
\text { (S/QF) }\end{array}$ & $\begin{array}{l}\text { Assure a product is safe; A wide number of food crises incidents lead people to compromise with } \\
\text { the safety and quality of food, which in turn deepens economic crises at the national and } \\
\text { international level }\end{array}$ & $\begin{array}{l}\text { (Shankar et al., 2018; Habibah } \\
\text { Abdul Talib et al., 2014) }\end{array}$ \\
\hline Prevent and Treat $(\mathrm{PT})$ & It means prevention of food waste and redistribution is a key factor of successfulness & (Aschemann-Witzel et al., 2017) \\
\hline $\begin{array}{l}\text { Government Policies or } \\
\text { Strategies }(\mathrm{GP} / \mathrm{S})\end{array}$ & $\begin{array}{l}\text { The role of the government in increasing food safety, quality, and security leads to an important } \\
\text { growth of government regulations that support or hinder the company's operations }\end{array}$ & $\begin{array}{l}\text { (Hutahayan, 2019; Taylor and } \\
\text { Taylor, 2015; Shankar et al., } \\
\text { 2018; Sharma et al., 2018) }\end{array}$ \\
\hline $\begin{array}{l}\text { Proper Use of Irrigation } \\
\text { (PUI) }\end{array}$ & It is used for the protection from microbiological contamination in fruits and vegetables & (Sharma et al., 2018) \\
\hline Fingerprinting $(\mathrm{F})$ & it is used for detecting contaminants in food by using many techniques like FTIR, SERS, etc. & (Sharma et al., 2018) \\
\hline
\end{tabular}


Table 3a. Linguistic variables and their corresponding TFNs (Kumar et al., 2019)

\begin{tabular}{ll}
\hline Linguistics variable & Corresponding TFNs \\
\hline Very low (VL) & $(0,0,0.1)$ \\
Low $(\mathrm{L})$ & $(0,0.1,0.3)$ \\
Medium $(\mathrm{M})$ & $(0.3,0.5,0.7)$ \\
High $(\mathrm{H})$ & $(0.7,0.9,1.0)$ \\
Very High $(\mathrm{VH})$ & $(0.9,1.0,1.0)$ \\
\hline
\end{tabular}

Table 4b. Linguistic variables and their corresponding TFNs (Dalalah \& Bataineh, 2009)

\begin{tabular}{ll}
\hline Linguistic variable & Corresponding TFNs \\
\hline No Influence (NO) & $(0,0,0.25)$ \\
Very Low Influence (VL) & $(0,0.25,0.5)$ \\
Low Influence (L) & $(0.25,0.5,0.75)$ \\
High Influence (H) & $(0.5,0.75,1.0)$ \\
Very High Influence (VH) & $(0.75,1.0,1.0)$ \\
\hline
\end{tabular}


Table 4. Experts' profile

\begin{tabular}{ccccc}
\hline Gender & Age & Experience in the food industry & Education & Current position \\
\hline $\mathrm{M}$ & 45 & +12 & $\mathrm{PhD}$ & $\mathrm{CEO}$ \\
$\mathrm{M}$ & 48 & +10 & $\mathrm{PG}$ & $\mathrm{CEO}$ \\
$\mathrm{F}$ & 51 & +15 & $\mathrm{DBA}$ & $\mathrm{CSCO}$ \\
$\mathrm{F}$ & 49 & +12 & $\mathrm{PG}$ & $\mathrm{CEO}$ \\
$\mathrm{M}$ & 53 & +20 & $\mathrm{PG}$ & $\mathrm{CSCO}$ \\
$\mathrm{F}$ & 55 & +25 & $\mathrm{PhD}$ & $\mathrm{CSCO}$ \\
$\mathrm{F}$ & 48 & +19 & $\mathrm{PG}$ & $\mathrm{CSCO}$ \\
$\mathrm{M}$ & 50 & +18 & $\mathrm{Phd}$ & $\mathrm{CSCO}$ \\
$\mathrm{M}$ & 56 & +21 & $\mathrm{Phd}$ & $\mathrm{CSCO}$ \\
\hline
\end{tabular}


Table 5. Fuzzy Delphi method analysis for finalising KSFs

\begin{tabular}{|c|c|c|c|c|c|c|c|}
\hline S.No & KSFs & Defuzzified Value & $\mathrm{A} / \mathrm{R}$ & S.No & KSFs & Defuzzified Value & $\mathrm{A} / \mathrm{R}$ \\
\hline 1. & APF & 0.73 & A & 31. & HRM & 0.54 & $\mathrm{R}$ \\
\hline 2. & I & 0.71 & A & 32. & CEC & 0.58 & $\mathrm{R}$ \\
\hline 3. & $\mathrm{PCO}$ & 0.71 & A & 33. & B & 0.64 & $\mathrm{R}$ \\
\hline 4. & $\mathrm{TF}$ & 0.56 & $\mathrm{R}$ & 34. & TA & 0.54 & $\mathrm{R}$ \\
\hline 5. & TBP & 0.73 & A & 35. & $\mathrm{CI}$ & 0.52 & $\mathrm{R}$ \\
\hline 6. & $\mathrm{PCH}$ & 0.56 & $\mathrm{R}$ & 36. & EO & 0.73 & A \\
\hline 7. & OCD & 0.72 & A & 37. & SCI & 0.89 & A \\
\hline 8. & ETE & 0.71 & A & 38. & PCT & 0.70 & A \\
\hline 9. & FS & 0.33 & $\mathrm{R}$ & 39. & LC & 0.33 & $\mathrm{R}$ \\
\hline 10. & FL & 0.67 & $\mathrm{R}$ & 40. & UTT & 0.69 & $\mathrm{R}$ \\
\hline 11. & FA & 0.33 & $\mathrm{R}$ & 41. & ETM & 0.65 & $\mathrm{R}$ \\
\hline 12. & $\mathrm{CNV}$ & 0.50 & $\mathrm{R}$ & 42. & UMR & 0.72 & A \\
\hline 13. & BS & 0.33 & $\mathrm{R}$ & 43. & P/MPS & 0.65 & $\mathrm{R}$ \\
\hline 14. & TI & 0.33 & $\mathrm{R}$ & 44. & AP & 0.65 & $\mathrm{R}$ \\
\hline 15. & K & 0.88 & A & 45. & NPD & 0.72 & A \\
\hline 16. & $\mathrm{PF}$ & 0.53 & $\mathrm{R}$ & 46. & BMA & 0.65 & $\mathrm{R}$ \\
\hline 17. & MA & 0.33 & $\mathrm{R}$ & 47. & IMT & 0.72 & A \\
\hline 18. & $\mathrm{AM}$ & 0.53 & $\mathrm{R}$ & 48. & $\mathrm{MC}$ & 0.49 & $\mathrm{R}$ \\
\hline 19. & LSO & 0.49 & $\mathrm{R}$ & 49. & BO & 0.53 & $\mathrm{R}$ \\
\hline 20. & VG & 0.56 & $\mathrm{R}$ & 50. & IB & 0.62 & $\mathrm{R}$ \\
\hline 21. & CIF & 0.72 & A & 51. & $\mathrm{CF}$ & 0.52 & $\mathrm{R}$ \\
\hline 22. & CSP & 0.67 & $\mathrm{R}$ & 52. & PAC & 0.33 & $\mathrm{R}$ \\
\hline 23. & $\mathrm{~L}$ & 0.71 & A & 53. & $\mathrm{ED} / \mathrm{SDF}$ & 0.52 & $\mathrm{R}$ \\
\hline 24. & GS/I & 0.53 & $\mathrm{R}$ & 54. & RA & 0.53 & $\mathrm{R}$ \\
\hline 25. & Q/CPTM & 0.70 & A & 55. & $\mathrm{CS}$ & 0.33 & $\mathrm{R}$ \\
\hline 26. & ET & 0.70 & A & 56. & $\mathrm{~S} / \mathrm{QF}$ & 0.33 & $\mathrm{R}$ \\
\hline 27. & TR & 0.71 & A & 57. & PT & 0.33 & $\mathrm{R}$ \\
\hline 28. & BP & 0.50 & $\mathrm{R}$ & 58. & $\mathrm{GP} / \mathrm{S}$ & 0.66 & $\mathrm{R}$ \\
\hline 29. & $\mathrm{P}$ & 0.69 & $\mathrm{R}$ & 59. & PUI & 0.33 & $\mathrm{R}$ \\
\hline 30. & $\mathrm{IM} / \mathrm{CC}$ & 0.52 & $\mathrm{R}$ & 60. & $\mathrm{~F}$ & 0.33 & $\mathrm{R}$ \\
\hline
\end{tabular}

(A) Accepted (R) Rejected 
Table 6. 6 $_{\mathbf{a}}$ The normalised direct-relation matrix for the dimensions

\begin{tabular}{lccc}
\hline & $\mathrm{D}_{1}$ & $\mathrm{D}_{2}$ & $\mathrm{D}_{3}$ \\
\hline $\mathrm{D}_{1}$ & $(0,0,0)$ & $(0.190,0.333,0.476)$ & $(0.238,0.381,0.524)$ \\
$2 \mathrm{D}_{2}$ & $(0.000,0.095,0.238)$ & $(0,0,0)$ & $(0.143,0.286,0.429)$ \\
$\mathrm{D}_{3}$ & $(0.000,0.047,0.190)$ & $(0.095,0.238,0.381)$ & $(0,0,0)$ \\
\hline
\end{tabular}

Table $\mathbf{6}_{\mathrm{b} .}$ The total relation matrix for the dimensions

\begin{tabular}{cccc}
\hline & $\mathrm{D}_{1}$ & $\mathrm{D}_{2}$ & $\mathrm{D}_{3}$ \\
\hline $\mathrm{D}_{1}$ & $(0.000,0.073,0.558)$ & $(0.216,0.488,1.258)$ & $(0.269,0.548,1.355)$ \\
$\mathrm{D}_{2}$ & $(0.000,0.125,0.595)$ & $(0.014,0.130,0.676)$ & $(0.145,0.371,1.030)$ \\
$\mathrm{D}_{3}$ & $(0.000,0.081,0.523)$ & $(0.097,0.292,0.878)$ & $(0.014,0.114,0.651)$ \\
\hline
\end{tabular}

Table 6. Defuzzified total relation matrix for the dimensions

\begin{tabular}{lllllll}
\hline & $\mathrm{D}_{1}$ & $\mathrm{D}_{2}$ & $\mathrm{D}_{3}$ & $R$ & $R+C$ & $R-C$ \\
\hline $\mathrm{D}_{1}$ & 0.154 & $\mathbf{0 . 5 8 2}$ & $\mathbf{0 . 6 4 7}$ & 1.383 & 1.887 & 0.879 \\
$\mathrm{D}_{2}$ & 0.196 & 0.222 & $\mathbf{0 . 4 6 8}$ & 0.886 & 2.073 & -0.301 \\
$\mathrm{D}_{3}$ & 0.154 & 0.383 & 0.204 & 0.741 & 2.06 & -0.578 \\
$C$ & 0.504 & 1.187 & 1.319 & & & \\
\hline
\end{tabular}

The values above the threshold $(0.45)$ are shown in bold. 
Table 7. Defuzzified total relation matrix for the dimensions

\begin{tabular}{|c|c|c|c|c|c|c|c|c|c|c|c|c|c|c|c|c|c|c|c|}
\hline & O & $\overrightarrow{\tilde{\oplus}}$ & 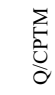 & 氠 & $\stackrel{|r| r}{|r|}$ & 어 & - & $\cong$ & $\vec{W}$ & 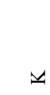 & U & 息 & $\stackrel{L}{\&}$ & $\sum_{S}^{\mathfrak{s}}$ & 宗 & $\xi$ & $\approx$ & $\begin{array}{l}u \\
+ \\
\approx\end{array}$ & $\begin{array}{l}u \\
\dot{2}\end{array}$ \\
\hline PCO & 0.08 & 0.13 & 0.09 & 0.09 & 0.07 & 0.07 & 0.12 & 0.11 & 0.14 & 0.09 & 0.14 & 0.14 & 0.15 & 0.13 & 0.12 & 0.15 & 1.84 & 3.45 & 0.23 \\
\hline TBP & 0.13 & 0.07 & 0.07 & 0.09 & 0.05 & 0.06 & 0.11 & 0.13 & 0.13 & 0.08 & 0.14 & 0.13 & 0.14 & 0.10 & 0.11 & 0.14 & 1.70 & 3.18 & 0.23 \\
\hline $\mathrm{Q} / \mathrm{CPTM}$ & 0.10 & 0.09 & 0.07 & 0.11 & 0.10 & 0.11 & 0.13 & 0.13 & 0.15 & 0.14 & 0.14 & 0.13 & 0.12 & 0.15 & 0.16 & 0.17 & 2.01 & 3.19 & 0.83 \\
\hline ET & 0.14 & 0.11 & 0.10 & 0.05 & 0.08 & 0.11 & 0.14 & 0.13 & 0.14 & 0.11 & 0.12 & 0.13 & 0.12 & 0.16 & 0.17 & 0.17 & 2.00 & 2.98 & 1.02 \\
\hline ETE & 0.14 & 0.12 & 0.13 & 0.11 & 0.05 & 0.12 & 0.13 & 0.14 & 0.15 & 0.13 & 0.14 & 0.13 & 0.13 & 0.14 & 0.14 & 0.17 & 2.07 & 2.93 & 1.21 \\
\hline $\mathrm{EO}$ & 0.14 & 0.12 & 0.09 & 0.08 & 0.07 & 0.04 & 0.12 & 0.12 & 0.14 & 0.12 & 0.13 & 0.14 & 0.14 & 0.14 & 0.15 & 0.17 & 1.92 & 2.82 & 1.01 \\
\hline L & 0.14 & 0.11 & 0.10 & 0.08 & 0.09 & 0.07 & 0.08 & 0.13 & 0.14 & 0.12 & 0.14 & 0.16 & 0.15 & 0.13 & 0.14 & 0.17 & 1.97 & 3.46 & 0.48 \\
\hline TR & 0.11 & 0.10 & 0.13 & 0.09 & 0.11 & 0.08 & 0.09 & 0.07 & 0.14 & 0.13 & 0.14 & 0.14 & 0.13 & 0.13 & 0.14 & 0.16 & 1.88 & 3.25 & 0.50 \\
\hline SCI & 0.11 & 0.11 & 0.06 & 0.04 & 0.05 & 0.03 & 0.09 & 0.06 & 0.08 & 0.09 & 0.11 & 0.14 & 0.13 & 0.11 & 0.11 & 0.14 & 1.46 & 3.41 & -0.50 \\
\hline $\mathrm{K}$ & 0.10 & 0.09 & 0.10 & 0.05 & 0.05 & 0.05 & 0.09 & 0.08 & 0.13 & 0.06 & 0.10 & 0.10 & 0.10 & 0.12 & 0.12 & 0.14 & 1.49 & 3.00 & -0.02 \\
\hline PCT & 0.10 & 0.11 & 0.05 & 0.03 & 0.03 & 0.03 & 0.07 & 0.05 & 0.11 & 0.08 & 0.06 & 0.11 & 0.11 & 0.10 & 0.10 & 0.12 & 1.25 & 3.03 & -0.53 \\
\hline CIF & 0.04 & 0.04 & 0.03 & 0.02 & 0.02 & 0.02 & 0.05 & 0.03 & 0.08 & 0.04 & 0.05 & 0.04 & 0.11 & 0.07 & 0.07 & 0.10 & 0.82 & 2.69 & -1.05 \\
\hline APF & 0.09 & 0.09 & 0.05 & 0.03 & 0.03 & 0.03 & 0.09 & 0.05 & 0.09 & 0.07 & 0.10 & 0.13 & 0.06 & 0.07 & 0.08 & 0.13 & 1.20 & 3.05 & -0.66 \\
\hline UMR & 0.04 & 0.04 & 0.03 & 0.02 & 0.02 & 0.02 & 0.04 & 0.03 & 0.09 & 0.07 & 0.07 & 0.07 & 0.07 & 0.04 & 0.10 & 0.12 & 0.88 & 2.61 & -0.86 \\
\hline NPD & 0.03 & 0.03 & 0.02 & 0.02 & 0.02 & 0.02 & 0.03 & 0.02 & 0.07 & 0.05 & 0.05 & 0.04 & 0.04 & 0.04 & 0.03 & 0.08 & 0.59 & 2.42 & -1.23 \\
\hline IMT & 0.11 & 0.11 & 0.08 & 0.04 & 0.04 & 0.04 & 0.11 & 0.09 & 0.14 & 0.11 & 0.13 & 0.14 & 0.14 & 0.10 & 0.11 & 0.09 & 1.58 & 3.83 & -0.67 \\
\hline$C$ & 1.61 & 1.47 & 1.18 & 0.98 & 0.86 & 0.91 & 1.49 & 1.38 & 1.95 & 1.51 & 1.78 & 1.87 & 1.86 & 1.74 & 1.83 & 2.25 & & & \\
\hline
\end{tabular}

The values above the threshold $(0.148)$ are shown in bold 
Table 8. The weighted super-matrix

\begin{tabular}{|c|c|c|c|c|c|c|c|c|c|c|c|c|c|c|c|c|c|}
\hline & PCO & TBP & $\mathrm{Q} / \mathrm{CPTM}$ & ET & ETE & EO & $\mathrm{L}$ & TR & SCI & $\mathrm{K}$ & PCT & $\mathrm{CIF}$ & $\mathrm{APF}$ & UMR & NPD & IMT & weight \\
\hline $\mathrm{PCO}$ & 0.01 & 0.02 & 0.01 & 0.02 & 0.02 & 0.02 & 0.02 & 0.02 & 0.04 & 0.04 & 0.05 & 0.03 & 0.04 & 0.03 & 0.03 & 0.04 & 0.034 \\
\hline TBP & 0.02 & 0.01 & 0.01 & 0.01 & 0.01 & 0.02 & 0.01 & 0.01 & 0.04 & 0.03 & 0.05 & 0.04 & 0.04 & 0.03 & 0.03 & 0.04 & 0.034 \\
\hline $\mathrm{Q} / \mathrm{CPTM}$ & 0.01 & 0.01 & 0.01 & 0.01 & 0.02 & 0.01 & 0.01 & 0.02 & 0.02 & 0.04 & 0.02 & 0.02 & 0.02 & 0.03 & 0.03 & 0.03 & 0.023 \\
\hline ET & 0.01 & 0.01 & 0.01 & 0.01 & 0.01 & 0.01 & 0.01 & 0.01 & 0.02 & 0.02 & 0.02 & 0.02 & 0.02 & 0.02 & 0.02 & 0.01 & 0.016 \\
\hline ETE & 0.01 & 0.01 & 0.01 & 0.01 & 0.01 & 0.01 & 0.01 & 0.02 & 0.02 & 0.02 & 0.01 & 0.02 & 0.01 & 0.02 & 0.02 & 0.01 & 0.015 \\
\hline EO & 0.01 & 0.01 & 0.01 & 0.01 & 0.01 & 0.01 & 0.01 & 0.01 & 0.01 & 0.02 & 0.01 & 0.02 & 0.01 & 0.02 & 0.02 & 0.01 & 0.015 \\
\hline L & 0.02 & 0.02 & 0.02 & 0.02 & 0.01 & 0.02 & 0.01 & 0.01 & 0.04 & 0.03 & 0.03 & 0.04 & 0.04 & 0.03 & 0.03 & 0.04 & 0.032 \\
\hline TR & 0.02 & 0.02 & 0.02 & 0.02 & 0.02 & 0.02 & 0.02 & 0.01 & 0.02 & 0.03 & 0.02 & 0.03 & 0.02 & 0.03 & 0.03 & 0.03 & 0.025 \\
\hline SCI & 0.09 & 0.09 & 0.10 & 0.10 & 0.09 & 0.09 & 0.08 & 0.09 & 0.03 & 0.07 & 0.06 & 0.06 & 0.05 & 0.13 & 0.14 & 0.11 & 0.090 \\
\hline $\mathrm{K}$ & 0.06 & 0.05 & 0.09 & 0.08 & 0.08 & 0.07 & 0.07 & 0.08 & 0.04 & 0.03 & 0.04 & 0.03 & 0.04 & 0.10 & 0.11 & 0.08 & 0.068 \\
\hline PCT & 0.09 & 0.10 & 0.09 & 0.08 & 0.08 & 0.08 & 0.09 & 0.09 & 0.05 & 0.05 & 0.03 & 0.04 & 0.05 & 0.09 & 0.09 & 0.10 & 0.075 \\
\hline $\mathrm{CIF}$ & 0.09 & 0.09 & 0.08 & 0.09 & 0.08 & 0.09 & 0.09 & 0.08 & 0.06 & 0.05 & 0.06 & 0.03 & 0.07 & 0.10 & 0.09 & 0.11 & 0.079 \\
\hline APF & 0.09 & 0.10 & 0.07 & 0.08 & 0.08 & 0.09 & 0.09 & 0.08 & 0.06 & 0.05 & 0.06 & 0.08 & 0.04 & 0.10 & 0.09 & 0.11 & 0.081 \\
\hline UMR & 0.15 & 0.14 & 0.15 & 0.15 & 0.15 & 0.14 & 0.14 & 0.14 & 0.16 & 0.17 & 0.16 & 0.15 & 0.13 & 0.04 & 0.08 & 0.09 & 0.118 \\
\hline NPD & 0.14 & 0.14 & 0.15 & 0.16 & 0.14 & 0.15 & 0.15 & 0.15 & 0.16 & 0.17 & 0.17 & 0.15 & 0.15 & 0.11 & 0.05 & 0.10 & 0.127 \\
\hline IMT & 0.18 & 0.19 & 0.17 & 0.16 & 0.18 & 0.17 & 0.18 & 0.18 & 0.21 & 0.19 & 0.20 & 0.23 & 0.25 & 0.13 & 0.15 & 0.08 & 0.167 \\
\hline
\end{tabular}

